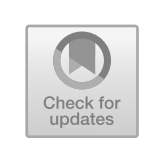

\title{
Silver, Rogues, and Trade Networks: Sangleyes and Manila Galleons Connecting the Spanish Empire and Qing China
}

This chapter examines the structure of trade in the South China Sea region through an analysis of merchant networks operating in this geographical area. Trade networks were long-distance partnerships that changed over time after the early arrival of Spanish and European missionaries to the Philippines, Macao, and Canton. The extent and complexity of the traders' operations and the brokerage system that integrated East Asian and European markets can be defined as early globalization, a kind of market integration ongoing before the 1820s' price convergence that conventional scholarship has used to date globalization.

The circulation of global goods in both Asian and Western regions, the intermediation of commercial agents through the commenda, and the creation of unofficial institutions in the unregulated market of the South China Sea stimulated the creation of dense trade networks where information, trust, loyalty, and territorial belonging were the key elements shaping the durability and sustainability of such networks.

The role of sangleyes (Chinese traders in the Philippines), acting as main trade agents connecting Manila with south China and the Americas through the Manila galleons and exchanges of American silver for Chinese goods, will be deconstructed and fully reexamined. Strong and intricate coalitions between the sangleyes, Hong merchants of Canton, and European traders demonstrate that both the Qing and Spanish empires had weak state capacity in regulating long-distance trade and accumulation

(C) The Author(s) 2021

M. Perez-Garcia, Global History with Chinese Characteristics, Palgrave Studies in Comparative Global History, https://doi.org/10.1007/978-981-15-7865-6_4 
revenues through maritime trade taxes. Seville and Marseille in western Mediterranean Europe and Macao and Canton in south China were the main nodes of this unregulated trade that operated through smuggling activities, bypassing state control, and ineffective mercantilist rules and decrees.

\subsection{New Comparisons Through the Mining of New Historical Data: The Great Divergence Through Consumption and Trade Networks}

Kenneth Pomeranz's main work, The Great Divergence (2000: 207), following Frank's Re-Orient (1998), and others in the California School such as Roy Bin Wong, Richard Von Glahn, James Lee, Robert Marks, Dennis Flynn studied why the Industrial Revolution occurred in Europe but not in China, and revisited the analysis of economic development and comparisons by focusing on Asian regions. Providing new data and comparing standards of living of developed areas in China, such as the lands of Jiangnan in the lower Yangtze Delta in Jiangsu province, and Europe (namely the Netherlands and Great Britain), Pomeranz demonstrated that some European regions had not accumulated the so-called vital advantage of the acquisition of raw materials, capital, and food supply prior to 1800. As a result, and as opposed to assumed explanations of development, some southern and central European regions were no freer of Malthusian pressures than other large economies such as their Asian counterparts.

Empirical evidence proved that the Industrial Revolution was not the outcome of European economic superiority, but rather a result of European "luck," and mainly England's fortune in establishing New World colonies that provided the energy sources and raw materials to power the revolution's early stages. Europeans experienced a similar process of development to some other regions of the world up until 1800. One example was the Jiangnan region of China. Pomeranz's research and subsequent works combined a comparative analysis, taking a purely local focus, with an integrative, global approach (Arrighi et al. 2003; Duchesne 2004; Goldstone 2008; Osterhammel 2009; Coclanis 2011). His perspective challenged the traditional and ideological Eurocentric view of Marx (1971), Weber (2001), and subsequent works of the twentieth century 
(Toynbee 1934; Polanyi 1944; Braudel 1979; Wallerstein 1980; Landes 1998) that were purely based on Western exceptionalism.

Once existing along the fringes of traditional historiography, characterized by fragmented and local narratives, global history in the aftermath of the Cold War and the fall of the Berlin Wall has gained extraordinary prominence in academic research. Typically, global history has been viewed as the history of the process of globalization, with a focus on modern economic growth of developed areas (Conrad 2016; Holstein 2015). Today, however, global history is seen as an interdisciplinary approach for the analysis of global processes through contacts, connections, socio-economic, and socio-cultural similarities, as well as differences of diverse territories around the globe (Middell and Naumann 2010; Schäfer 2004).

A major pitfall in comparative, cross-cultural studies with a longue durée chronology is that some ambiguities and vagueness are prone to appear (Sawyer 2015; Trivellato and Heudre 2015; Armitage et al. 2015; Krishan 2014; Struck et al. 2011). Europe is deeply diverse-there are great differences in northwestern Europe between Great Britain or the Netherlands, for example. For Asia, and China in particular, the same applies if we are referring to the Yangtze region or its prefecture areas comparing to less developed regions such as Gansu, Anhui or Yunnan, but economic differences between both areas are analysed during the period of the Industrial Revolution and the mid-Qing dynasty. Some scholars have focused too intensely on the debate around the great divergence, others have jumped into conclusions about India and China having had higher economic development levels than Europe pre-1800, or have attempted to use values of GDP for the year IBC, which seems a weak and unreliable way to measure economic growth even in 1700 (Pomeranz 2000; van Zanden and Prak 2013; Maddison 2007; O'Brien and Deng 2017; Levi 2019).

This chapter focuses on two city ports, Macao and Marseille, both geostrategic entrepôts for international trade in the eighteenth century since they represented the socio-economic nodes integrating Western and East Asian markets allowing the circulation of Western goods into south China and Chinese goods into western Mediterranean markets. Rather than peripheral economies of early modern Europe and China, these areas played a dominant role in the development of Europe and Asia as did other northwestern European countries such as Great Britain (and the British world) (Berg 2019; Washbrook 1997; Bryant 2006) and the 
Netherlands (O'Rourke and Williamson 2004; Broadberry et al. 2018; van Zanden and et al. 2012; Li and van Zanden 2012).

Presenting new historical data from a wide variety of communities, villages, regions, and polities, collected through emerging digital tools, moves away from core or central economic areas and offers a polycentric approach when comparing East Asian, European, and American regions (Perez-Garcia 2018; de Sousa 2019; Cao and Flynn 2019; Ibarra 2017; Nakajima 2018; Hausberger and Ibarra 2018). This more holistic view of the world economic system (Frank 1998) seems to be a more accurate scale of analysis than big observations about nation-states.

Using findings from the GECEM Project Database, I focus on trade networks and the consumption of Chinese goods in western Mediterranean Europe (silk, tea, and porcelain), through the economic axis Marseille-Seville. ' European goods (tobacco, wine glasses, clocks, mirrors, wines, and liquors) (Perez-Garcia 2019) were introduced into south China through the trade hub of Macao-Canton, which was connected to the Iberian empires via the Manila galleons. While using a comparative methodology I thus decentralize the core world economic zones and analyse global conjunctures through regional cases.

By and large, scholarship has focused on England and its colonies, especially when looking at the development of the British empire with its strong trade orientation during the seventeenth and eighteenth centuries (O'Rourke and Williamson 2004; Brewer 2010; Broadberry et al. 2017). It was a society of traders and consumers, and since the mid-1970s economic historians have concentrated their explorations on the British world searching for the roots of the consumer society. England could be identified as a nation of wholesalers, retailers, peddlers, and consumers. The new consumers, largely the urban elites or middle classes, desired and sought out colonial goods such as tea, sugar, or tobacco. This demand spurred the proliferation of networks of retailers and shops in eighteenth-century England (Fairchilds 1993).

In particular, Neil McKendrick led economic historians in the search for the birthplace of the consumer revolution during the first Industrial Revolution. The 1980s saw increased historiographical interest in finding the origins of mass consumer societies, and England, as the centre of

${ }^{1}$ For more detailed information see GECEM Project (Global Encounters between China and Europe: Trade Networks, Consumption and Cultural Exchanges in Macau and Marseille, 1680-1840), www.gecem.eu. 
the economic world during the early modern period, was the pivotal axis of historical analysis. The main features of the so-called "open societies" were changes in patterns of consumption that fostered economic growth and new technological changes, where consumer motivations to acquire new goods, market integration, the creation of new fashions and tastes, and an increase in disposable income to spend on luxury goods (i.e. goods not intended to cover basic necessities) all occurred (McKendrick 1982).

During the period of global economic expansion of European regions, consumers and traders of Chinese goods had fostered market integration with East Asia since the sixteenth century. There is a solid scholarship analysing the impact of Chinese goods in Europe (Braudel 1992; Batchelor 2008; Perez-Garcia 2013; Gerritsen and McDowall 2012; McNiel and Riello 2016; McCants 2018; de Vries 2008), as well as that one which studies the arrival of Europeans to the Americas and East Asia during the sixteenth century (de Sousa 2019; Oka 2018; Nakajima 2018).

While in Ming and Qing China there was no consumer revolution on the same scale as in Northern Europe (namely London and Amsterdam), changes in patterns of consumption did gradually occur in late Ming China due to the introduction of American crops (sweet potato, potato, corn, chili) (Perez-Garcia 2018; Ho 1979; Elvin 1973), the increasing demand for American silver through the Manila galleons (Von Glahn 1996; Irigoin 2009; Flynn and Giraldez 2010) (connecting the Spanish trade in Manila with south China), and, later in Qing China, the introduction of goods such as clocks, mirrors, European wine and liquors, and tobacco. These latter commodities changed fashions and, in turn, lifestyles among the Chinese elites.

A key issue to unveil is observing the flows and channels of distribution of goods and its impact in the seventeenth and eighteenth centuries with the arrival of the foreign (non-Han) Qing dynasty to the Beijing Court. The same can be applied to the Spanish empire when the Iberian Union of Crowns came to an end in the mid-seventeenth century with the arrival of the French dynasty, the Bourbons, to the Spanish throne in the early eighteenth century. Both the Qing and Bourbon dynasties implemented stiff mercantilist rules aiming to control trade and the economy. A relevant question is to analyse the real effect of these policies on the socio-economic and political agents and whether a centralized power and autocratic regime had a reverse impact on the economic development 
fostering the rise of unofficial institutions to bypass the rigid government regulations.

There were convergences and regional differences up to the eighteenth century, and Macao, connecting with south China, and Marseille, in Mediterranean Europe, can both be defined as transnational and transcultural sites due to the international trade communities that settled in those areas. Macao and Marseille were geostrategic sites as their privileged location in the South China Sea and Mediterranean Sea, respectively, allowed them to develop trade links with other surrounding ports and external areas for international trade and distribution of commodities. Marseille was the transnational entrepôt that connected Europe with Asia through the Levantine routes, mainly through the trade activities of Aleppo and Armenian merchants from New Julfa (Aslanian 2011). Marseille also had links to western Mediterranean commerce through Seville-Cadiz as the main point of entry for Asian goods into Europe. Macao was linked with the West via the commerce with India and also through the Manila-Acapulco galleons.

This new case study comparing Macao and Marseille aims to challenge the research which has treated China and Europe as a whole, without considering regional socio-economic specificities (i.e. the fact that northern Chinese markets and trade groups had a different way of working to those in southern China, mainly in the areas of Guangdong and Fujian; and the same was true between northern and southern European markets) (McDermott 2013; Ma and Yuan 2016). Such territorial holistic and homogeneous schemes and frames of analysis go hand-inhand with national historical narratives whose objective is to reconstruct and present the exceptional or hegemonic position of the European leading economies during the period of the first Industrial Revolution.

Looking at Macao and Marseille, two port cities located on the peripheries of China and Europe, allows us to accurately observe how changes in consumer behaviour, prompted by the intermediation of traders, were correlated with economic growth and how the state bureaucracy and mercantilist policies facilitated or impeded the circulation and entry of overseas goods. The common features shared in both areas is the crosscultural trade that stimulated local economies, the internal organization of trading families, as well as the assimilation of different cultural forms. Within this context some concepts such as trust, loyalty, and mediation, which strengthened international trade networks, were vital in these heterogeneous groups. The analysis of patterns of consumption, as well 
as possible differences and similarities among these groups, can give us a full view of the transmission of cultural values by these transnational communities. Investigating the introduction of Chinese goods into Europe and Western goods into China might allow us to better observe the process of socio-economic and cultural assimilation. The main mediators for such processes of socio-cultural transfer through the consumption of new goods were the groups of merchants defined as "vicarious consumers" (Perez-Garcia 2013) who stimulated new cultural practices, business intermediation, and social habits in the territory they settled in. Merchants were at the centre of this intricate map of connections. They were agents in the distribution, marketing, and selling of goods, stimulating the demand for new goods and creating new needs, not only in the upper social ranks but also among ordinary people.

The analysis of socio-economic transfers and the acquisition of new cultural forms between regions of south China and western Mediterranean Europe, through the economic circuits of Macao and Marseille, might allow us to better understand the connections and global encounters in between far-flung regions. During the early modern period, mainly in the eighteenth century, markets tended to be integrated on a global scale, and the analysis of such connections at a regional level might allow us to identify possible divergences and/or convergences.

The empirical grounding we can gain by cross-referencing European and Chinese sources might help to illuminate the global process of economic development between a specific territory of China, with the case study of Macao, and its European counterpart, Marseille. Therefore, such specific analysis is based on a jeux d'échelles [game of scales], from a micro perspective (Revel 1996; Haupt and Kocka 2009), by analysing trade networks, to a macro perspective, by taking global markets and goods as the main axis of comparison. This approach will help us surpass the conventional division between rich and poor or developed and underdeveloped countries, providing a new case of two different models of development, and how trade networks and merchants shaped cultural models, changed consumer behaviour, as well as political and economic institutions. Thus, key issues in the debate on globalization are being addressed, as new forms of globalization contributed to transform fashions and channel new cultural identities beyond traditional economic models of interpretation (O'Rourke and Williamson 2004).

Instead of looking at this issue from a Eurocentric view (Frank 1998), the focus is based on analysing and discussing the interactions between the 
main social agents such as consumers, travellers, traders, and the objects themselves. These were the principal socio-economic and cultural mediators in the process of changing tastes and fashions through the circulation of commodities. Scholars of this subject have focused mainly on the analysis of Chinese objects circulating in Europe in the early globalization (Gills and Thompson 2006), but what about the chains of European goods in China? Thus, it is relevant to introduce the concept of "differential consumption" of Chinese goods in Europe and European goods in China. Establishing typologies of goods and the differentiation of consumers such as the elites and non-wealthy social groups can give us a more accurate picture of the social circulation of certain goods that were intended for luxury markets, as well as how fashions and new consumers increased the demand for such goods.

The historical sources used for this research come from the archives of Macao (Arquivo Historico de Macao, hereafter AHM), Marseille (Archive de la Chambre de Commerce de Marseille and Archives Departamentales des Bouches-du-Rhône, hereafter ACCM and ADBDR), and also Seville and Murcia (Archivo General de Indias and Archivo Historico Provincial de Murcia and Archivo Historico Provincial de Sevilla, hereafter AGI, AHPS, and AHPM). Probate-inventories, trade records, and private merchant letters are crucial evidence to shed light on: (1) changes in consumer behaviour; (2) typologies of goods introduced in south China and Europe and the global drain of American silver which was accumulated by Chinese traders and intermediaries, such as the Chinese merchants of Manila (the so-called sangleyes), who evaded the state supervision; (3) the identity of the consumers (elites and/or ordinary people); (4) the socio-economic agents, traders, who introduced such goods; and (5) the official and non-official trade system, and state capacity to regulate such markets. This micro-analysis, which pays attention to socio-economic agents and commercial networks as mediators in the introduction of new goods creating a new market, uncovers the microfoundations of the great divergence. In addition, it shows how institutions and officials of the Qing state sought to create a whole economic apparatus for sustainable economic growth. 


\subsection{Stereotypes, Casts, and Imagined Communities in the Philippines: The Chinese Sangleyes}

From the sixteenth century onwards, after the arrival of European (mainly Portuguese and Spanish) communities in south China (Macao, Canton) and Manila in the Philippines, the role of itinerant Chinese traders, the so-called sangleyes, is of utmost importance to understanding the influx of American silver into China, exports of Chinese goods, and imports of Western commodities. In the eighteenth century, in a description of the Philippines, Jesuit Father Pedro Murillo Velarde mentioned the transnational feature of the city of Manila inhabited by communities from territories of diverse continents. They talked in Spanish adapted to their own languages which on many occasions made the communication very difficult. $^{2}$

The term sangleyes has proved difficult to define within the scholarship. It has been mistakenly interpreted by historians as one derived from the Hokkien language (Fujian) referring to Chinese merchants settled in Manila that came from the south China provinces of Guangdong and Fujian, who were allowed to trade in the Philippines ${ }^{3}$ (Wickberg 1964; Ollé 2002, 2018; Borrego 2016; Gil 2011; García-Abasolo 2011). Historians of the Spanish empire often and erroneously refer to the German Anthropologist Berthold Laufer's argument, who in his work The Relations of the Chinese to the Philippines Islands (Laufer 1907: 259) mentioned the large Chinese community in Manila from Fujian provinces (Ruiz-Stovel 2009: 56; Borrego 2016: 214).

However, Laufer does not mention that sangleyes is a term from the Hokkien language, and he makes a rather sloppy and vague interpretation of the works describing China by the Dominican friar Domingo Fernandez de Navarrete (1610-1689) and by early seventeenth century Antonio de $\mathrm{Morga}^{4}$ (1609) who was a royal official of the Spanish crown in the Philippines. Some scholars mention that the term itself might derive from Hokkienese language, sengli, meaning "trader," others

2 BNE, Pedro Murillo Velarde, Geographia historica de las Islas Philipinas, del Africa y de sus islas adyacentes, Tomo VIII, Madrid, 1752, p. 52.

3 BNE, de Morga, A., Sucesos de las islas Filipinas, México: Casa de Geronymo Balli, 1609.

4 BNE, de Morga, A., Sucesos de las islas Filipinas, México: Casa de Geronymo Balli, 1609. 
suggest shanglii, "traveling merchants," or changlai, "come regularly" (Brook 2008: 167). This scholarship has mainly taken this thesis for granted from Laufer's work which should be deeply revised (Laufer 1907: 263).

According to Benedict Anderson, and as I also demonstrate, the Hokkien thesis for the origin of the sangleyes community is unsustainable as this interpretation derives from the current wave of national micro-histories that claim for the legitimation of "imagined communities" (Anderson 1988). Such imaginaries are fed by nationalism and patriotic local narratives, and "it is a lesson for our nationalistic age that neither the Spaniards nor the Hokkienese could yet imagine 'Chinese"' (Anderson 1988: 6). The "Chinese" groups of the Ming and Qing dynasties did not describe themselves as sangleyes and could not portray the political landscape of the emerging nation-states of the nineteenth and twentieth centuries.

Chinese (or southeast Asian) itinerant communities, which were mainly orientated to business activities, did not refer to themselves as sangleyes. Sangleyes is a term that we only find in the Spanish manuscripts of the period (i.e. de Morga's description of the Philippines, the Boxer Codex, among the most relevant), and in the Spanish historical sources of the Archivo General de Indias at the sections Real Audiencia, Filipinas, and in the manuscripts from Dominican, Franciscan, and Jesuit communities. In the Ming shiliu 明实录, ${ }^{5}$ Qing shilì 清实录, ${ }^{6}$ or other Ming and Qing dynasty sources such as trade records and memorials of the First Historical Archives of China in Beijing, there is not any record mentioning the term sangleyes. The Ming shili ${ }^{7}$ does mention the abundant number of Fujianese traders settling down in Manila, but not the term sangley (Horsley 1950: 78, 186).

It was a stereotyped Western (Spanish) Catholic concept of cast (see Illustration 4.1) referring to the Chinese in Manila who were among the

5 SJTUL, Ming shilu (Veritable Records of the Ming Dynasty), Taipei: Academia Sinica Institute of History and Philology, 1962.

${ }^{6}$ SJTUL, Qing shilu (Veritable Records of the Qing Dynasty), Beijing: Zhonghua Publishing Company, 2008.

7 SJTUL, Ming shilu (Veritable Records of the Ming Dynasty), Taipei: Academia Sinica Institute of History and Philology, 1962. 


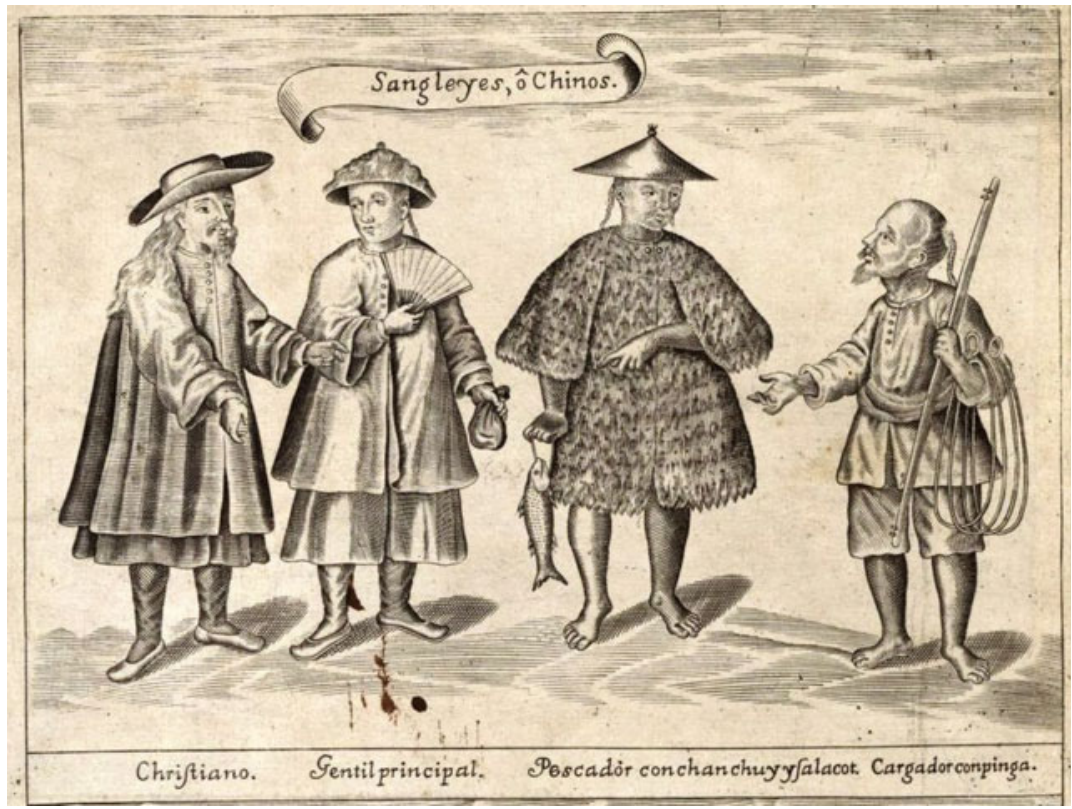

Illustration 4.1 Sangleyes or Chinese Casts in the Philippines.

Source: LC, Murillo Velarde, Pedro, and Nicolás De La Cruz Bagay. Carta hydrographica y chorographica de las Yslas Filipinas: dedicada al Rey Nuestro Señor por el Mariscal de Campo don Fernando Valdes Tamon Cavallo del Orden de Santiago de Governador y Capitan. [Manila: Publisher Not Identified, 1734] Map. https://www.loc.gov/item/2013585226/

diffuse social group of traders, artisans, smugglers, and pirates or corsairs ${ }^{8}$ that were engaged in contraband activities making the routes from Amoy, Fuzhou (Blussé 1990), Formosa, Canton, Macao, or Nagasaki (Nakajima 2018; Boyajian 2008; Ptak 2003; Qiu 1995). This is defined as unofficial trade nánbán 南蛮 (southern barbarian), very well studied by Mihoko Oka who has argued that it "meant vaguely the uncivilized peoples belonging to the south of China" (Oka 2018: 163-182). The sangleyes might have some parallels with the term wokou which Oka defined as

8 Caroline S. Hau mentions the possibility of referring to sangleyes as pirates, lannang (Hau 2003: 192; Scott 1994: 190, 279; Hau 2014: 9). 
"mixed-race smugglers mainly comprising Chinese merchants" for the Japan overseas trade relations in south China (Oka 2018: 165; Borao 2005: 25-53).

Sangleyes is a transliteration in the Spanish sources of the Chinese term 商人来 shāngrén lái (merchant who arrives). Spanish scribes and notaries who settled in Manila in the second half of the sixteenth century did not know how to write or speak Chinese. Spanish scribes might hear about the term shāngrén lái referring to Chinese traders and they transliterated the term as sangleyes. ${ }^{9}$ It was likely a general term to identify merchants, mainly from other races and ethnic groups, from Chinese origins. Also, any merchant from Asian origins was labelled as sangley in the Spanish sources (the only historical sources mentioning this term). In the Boxer Codex the first allusion to sangley is when the author is describing the island of Brunei, its lands, its people, and how Brunei became an Islamic state circa fourteenth century under the mandate of the lord of the city Sultan Yusuf. The quote says:

"...not satisfied with this and as a young man with no other goal than to find new lands boarded all his people and sailed back through the northeast and after some days reached port in Chinese lands and requested license to stay and landed to go visit the King of China who he recognized as superior King; and the King of China confirmed him back as King, providing him of badges and weapons that today the King of Borney [Brunei] still has and seeing that sultan Yuso [Sultan Yusuf] was not married ceded him a sangleya [sangley woman] that happened to be related with the King of China. She was lordess of a city called namtay [Nantay] in the kingdom of China..."10

In their transcription and translation of the Boxer Codex from Spanish to English, George B. Souza and Jeffrey S.Turley, likely echoing previous

${ }^{9}$ From the sixteenth century onwards, we have many examples in the Spanish sources for such transliterations of Chinese terms. Champan 三 板 [sam pan] refers to a variety of Chinese and Japanese fishing ship that was often mentioned in the Spanish early modern historical sources. Such term is frequently mentioned in the sources of the Archivo General de Indias in the catalogue of the Philippines related to commerce of East Asian ports such as Nagasaki, Canton, Macao, or Manila, among others.

See Diccionario Maritimo Español, José de Lorenzo, Gonzalo de Muga, Martín Ferreiro, 1865. According to this dictionary, this word was designated for vessels, 三 板 [ sam pan], whose meaning is "three thick planks."

${ }^{10}$ Indiana University Digital Library (hereafter IUDL), Boxer Codex, [manuscript], ca. 1590, f. $74 \mathrm{v}$. 
interpretations such as Laufer's and others, mention that sangley is a transliteration from Chinese 常來 cháng lái meaning "frequently come" and it was used "for Chinese visitors or settlers in the Philippines, primarily but not exclusively from Fujian" (Souza and Turley 2015: 402). The quotation above portrays a sort of fictional story relating the myth of the Muslim Brunei Sultanate and its relationship with the emperor of China who gave to the sultan a sangley woman [sangleya] as a wife. The passage mentions that this woman was a relative of the emperor of China and she was the ruler of the city of Nantay (the Fujianese city of Quanzhou according to Souza and Turley $(2015: 402,403)$. This proves that the manuscript itself does not mention any passage that explicitly states that sangley is a word from Hokkienese or the origins of the term that the above-mentioned and ongoing historiography (Crossley 2016) keeps repeating without any solid foundation and deep analysis of the term and historical context.

Also, the Spanish Augustinian friar Martin de Rada (1533-1578) mentioned in his description of China that the indigenous people of the Philippines islands "call China sangley, and the Chinese merchants themselves call it zhonghua" meaning "middle kingdom" (Souza and Turley 2015: 559, 560). ${ }^{11}$ According to Charles Boxer, many names were used to refer to China, or the kingdom of Cathay as Marco Polo called it, and Chinese communities were corrupted from southern China languages (i.e. Hokkienese or Cantonese). People from Burney [Brunei] were also called Chinese by natives of the Philippines (Souza and Turley 2015: 560, 561; Boxer 1953; Boxer 1968). ${ }^{12}$ This does not make any sense and according to Boxer there were errors in the transcription and copies of Rada's work and subsequent descriptions and views by Spanish friars and travellers in the Philippines.

The misinterpretations around the sangleyes mainly stem from Spanish (Santamaría 1966; Folch 2002; Ollé 2011; García-Abasolo 2011), Chinese (Hu-DeHart 2013), and Taiwanese ${ }^{13}$ scholarship. Rada had an incomplete image of China (Sola 2018: 176) and created a view and

11 IUDL, Boxer Codex, f. 213r., f. $213 \mathrm{v}$.

12 IUDL, Boxer Codex, f. 213v., f. 214r.

13 Here I just mention some works of Taiwanese scholarship which proves the incremental and shallowness of the ongoing research in this topic (Li Yu Zhong 2001: 31-48; Fang Chen-Chen 2010: 146-198, 2017: 179-227). 
opinion of Chinese society with the aim to project a distorted imaginary (Gruzinski 1988, 2014) to ecclesiastic and civil officials of Spain in the context of Catholic Counterreformation and Inquisition prosecutions. This imaginary and idealistic view was also portrayed in the Boxer Codex which described the rich lands and peoples of the Philippines and nearby regions such as China.

The economic crisis at the end of the reign of Philipp II and at the beginning of Philipp III is a plausible thesis to explain the detailed accounts found in the Boxer Codex. The goal of the Codex, written at the end of the sixteenth century under the administration of Luis Pérez Dasmariñas, Governor General of the Philippines, was probably to convince the authorities, and the king himself, of Spain's need to extract revenues from the rich lands and economic resources of the Philippines and East Asia in a period in which the Spanish monarchy was in bankruptcy (Elliott 1986, 2002; ; Yun-Casalilla 2019; Lynch 1994). One of the illustrations of the Codex (see Illustration 4.2) portrayed a married couple of sangleyes, ${ }^{14}$ which the manuscript describes as rich kings from Cathay (the middle kingdom). Sangleyes were mainly merchants and not the sort of nobles or aristocrats as the image portrayed, probably echoing the image of the elites and nobility of Spain. This was likely an unreal image, then, but one with the aim of persuading local authorities of Spain to maintain the presidios, encomiendas, and colonial institutions of the Philippines, to extract potential economic benefits.

Beyond the etymological meanings and historiographical disputes such denomination had a socio-cultural connotation as a way to refer to a nonCatholic community which was very common within the context of pure blood in the Iberian empires when new colonies in the Americas and Asia were incorporated into the Iberian kingdoms. The conversion to the Catholic faith of peoples and native American and Asian communities that had a lower social status according to doctrines of the European Counterreformation was the main goal of the Spanish settlers in the Philippines. This is the more plausible thesis as it was the Spanish who referred to the Chinese communities as sangleyes that should be Christianised (Horsley 1950: 106, 107, 108). A different issue is the vernacular language these transients and migrants from Fujian and Canton spoke when settled in

14 IUDL, Boxer Codex, f. 204r, f. 222r.-227r. 
Illustration $\mathbf{4 . 2}$

Couple of Sangleyes as in the Boxer Codex

Source: IUDL, Boxer

Codex, f. 204r, f.

222r. $-227 \mathrm{r}$

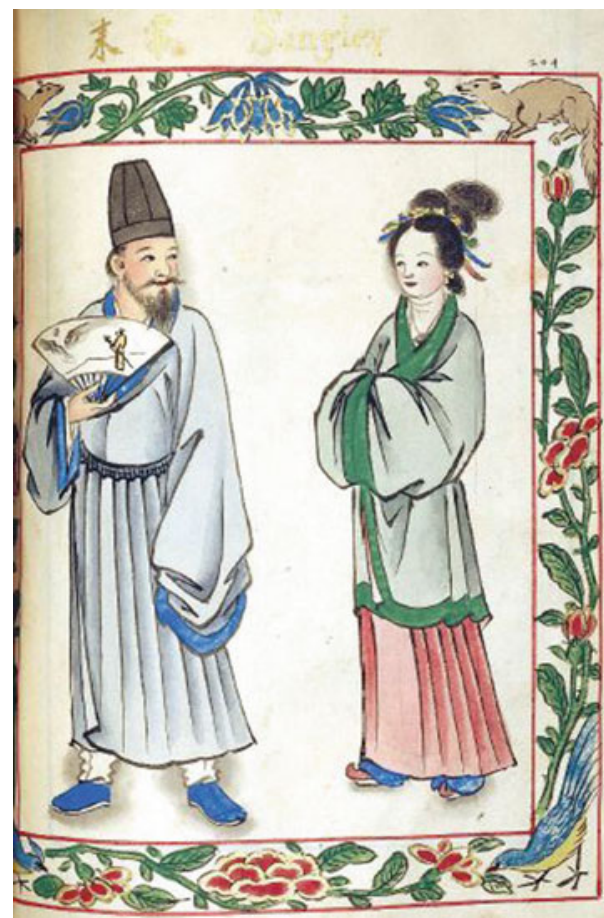

the Philippines by the "population that the Spanish called the sangleyes" (Klöter 2011).

Therefore, it is plausible that the term sangleyes was aimed to stereotype a native community that should be converted to the Catholic faith, as well as to the customs and traditions of the Spanish crown. They were stereotyped in the same way as the native communities of the Americas, the "indios" [Indians], who were converted by the Spanish conquistadors. In 1594, a royal order was delivered to the governor of the Philippines Gómez Pérez Dasmariñas to report and provide a remedy to the affronts and insults the "indios sangleyes" [Indian sangleyes] ${ }^{15}$ received after arriving in Manila from China to engage in trade and business.

In 1582 friar Juan Bautista, vicar of the village of Miton (Philippines), wrote a letter to Domingo de Salazar, the bishop of the Philippines,

15 AGI, Filipinas, 339, L. 2, f. 55r-56r. 
regarding the grievances the sangleyes received who came back without any will to settle down in the village of Miton. In the letter Bautista expresses his frustration in dealing with the sangleyes as he did not understand their language (Chinese) and he also mentioned the complex interactions with the sangleyes community orientated in business and how they enslaved their own people for their business. The letter reads:

"I attempted to bring up what your eminence sent me from the sangleies [sangleyes] directly and I have to sincerely say that after giving much thought to it for another couple of hours thanks to the naughty youngster that also is unable to understand a thing I asked since after twenty times [many many times] I asked they answered differently—they are indios [Indians] after all and that until I was able to find out the real amount they all screamed around saying that 400 pesos they had paid taking the cargo because they had paid forty men at ten pesos each but I found out that they did not pay 140 because the men that went were thirty five rented men that were not paid more than seven pesos of those twenty or twenty four. The rest were slaves and servants [esclavos y criados] of the same sangleies because who had men to give gave no money. In reference to the depopulation of Indians in this land the sangleies I have asked ship captains to bring more people to live there a captain responded that he had brought fifty, another that he had brought twenty, and another one forty, all of them with the aim of settling here. My calculations are that a bit more than two hundred, as I asked about how they were treated and I witnessed how sometimes they forced rreos [prisoners] and in jornadas [working days ...] other times harassing the rest of the indios as usual and particularly by buying their mercaderia [merchandise] at a lower price and by force the alcaldes mayores [mayors] and sometimes taking Spaniards to their homes and inspecting what they have under their beds and in the boxes and purses, forcing them to open the boxes and purses and buying the goods at a very low price or no price and many other things that I will list and they regretted and came back because they did not want to settle and in this town of Miton of the houses that of the ten houses that there were now there are six empty and from these houses around eighteen or twenty people indios and two or three years approximately fifty people that were living here and wanted to settle and in the words of all of the people living in Miton there are around three hundred indios, men, that are missing and complain about many other things I could say ... In Miton, today Tuesday of $1562 .{ }^{16}$

16 Translation from Spanish to English, keeping original narrative as literal as possible. AGI, Filipinas, 84, n. 26. 
Such misinterpretations of the lands of the Middle Kingdom and its people by the early arrival of the Spanish Augustinians and Dominicans were likely a product of the project of evangelization and socio-economic and political domination of new lands under the reign of Philip II. The above manuscripts and descriptions of China and the East Asian lands showed that there was a lack of knowledge and adaptation by the European (mainly Spanish) newcomers. It was not until the arrival of the first Jesuits to China in the last quarter of the sixteenth century when we find a more accurate view and description of China through European eyes as they were the best learners of the Chinese language and Jesuits also created the more accurate dictionary from Chinese to Latin. This broke down the stereotypes and distorted images constructed by Dominicans, Augustinians, and Spanish conquerors.

There is not any similar reference, as in the way we find in the Boxer Codex and other manuscripts, about sangleyes in the Jesuit manuscripts of the late sixteenth, seventeenth, and eighteenth centuries. The French Jesuit Jean-Baptiste Du Halde (1674-1743) known in Chinese as Dì Hèdé 杜赫德 prepared the Description de la Chine in 1735, one of the best encyclopaedic works on China about the culture, society, politics, economy, and history of the Middle Kingdom. There is not one mention about the term sangleyes in Du Halde's work, which demonstrates that the term sangley is a Spanish construct. The accuracy of Du Halde's work is seen in his precise description of Chinese silk and porcelain production, ${ }^{17}$ and local producers of these commodities in Europe used his work to discover the secrets of production of these highly appreciated Chinese goods.

The arrival in Asia of the first Jesuit, San Francisco Xavier, founding member of the Societatis Iesu in 1552, and thereafter, Father Matteo Ricci in 1583, and his fellow Jesuits meant that knowledge of Asia and China in Europe became much improved (Meynard 2006). The number of Jesuits from different European territories who came to China increased from the end of the Ming dynasty until the mid-Qing dynasty, with the main countries of origin being Portugal, France, and Italy (see Table 4.1).

17 The Beijing Center of Chinese Studies Library (hereafter TBCL), Rare Book Collection: Jean-Baptiste Du Halde, Description Geographique, Historique, Chronologique, Politique, et Physique de l'Empire de la Chine et de la Tartarie Chinoise, vols. 1-4, Paris: P.-G. le Mercier, 1735. 
Table 4.1 Origins of Jesuits settled in China (1552-1701)

\begin{tabular}{lrl}
\hline Origin & No. Individuals & $\%$ \\
\hline Belgium & 11 & 5,44 \\
Chinese & 10 & 4,95 \\
Dalmatian & 1 & 0,49 \\
Florentine & 1 & 0,49 \\
French & 49 & 24,25 \\
German & 13 & 6,43 \\
Spanish & 5 & 2,47 \\
Italian & 32 & 15,84 \\
Portuguese & 64 & 31,68 \\
Macanese & 2 & 0,99 \\
Navarra & 1 & 0,49 \\
Neapolitan & 2 & 0,99 \\
Piedmontese & 1 & 0,49 \\
Palermitani & 1 & 0,49 \\
Polish & 3 & 1,48 \\
Sicilian & 5 & 2,47 \\
Tunkin & 1 & 0,49 \\
Total & 202 & 100 \\
\hline
\end{tabular}

Source: Author's own elaboration using data from the Matteo Ricci Institute of Macau/Archivum Romanum Societatis Jesu (hereafter AMRIM/ARSJ), Japonensis Sinica [hereafter Jap.Sin.] 187, Epistola Sinarum, folio (hereafter f.) $3-5 \mathrm{v}$

Their main aim was to organize the Catholic missions in different provinces (see Map 4.1) serving as the main agents of cultural and socioeconomic exchanges between Europe and China. Such exchanges were presented in the form of the introduction in China of Christian values and the adaptation to Chinese beliefs and ethics such as Confucianism (Meynard 2015), Taoism, and Buddhism, as well as trans-linguistic and cultural forms by which Western standards were adapted to Chinese culture (Hosne 2011; 2013). This follows the Jesuit classic accommodation method to adapt themselves by preaching in the vernacular language and learning the customs of the place where they had settled down: "ad usum loci, in quo vivitur accomodatus" (Muller 2016; Mungello 1989; Elison 1973).

Ricci when arrived in China at the age of thirty years old, he was calling in Europe for priests that should be men of "good," but also men of "talent" (Latourette 1929: 83). Jesuits also acquired a Chinese name as a sign of adapting to the culture and habits of the unknown Far East 


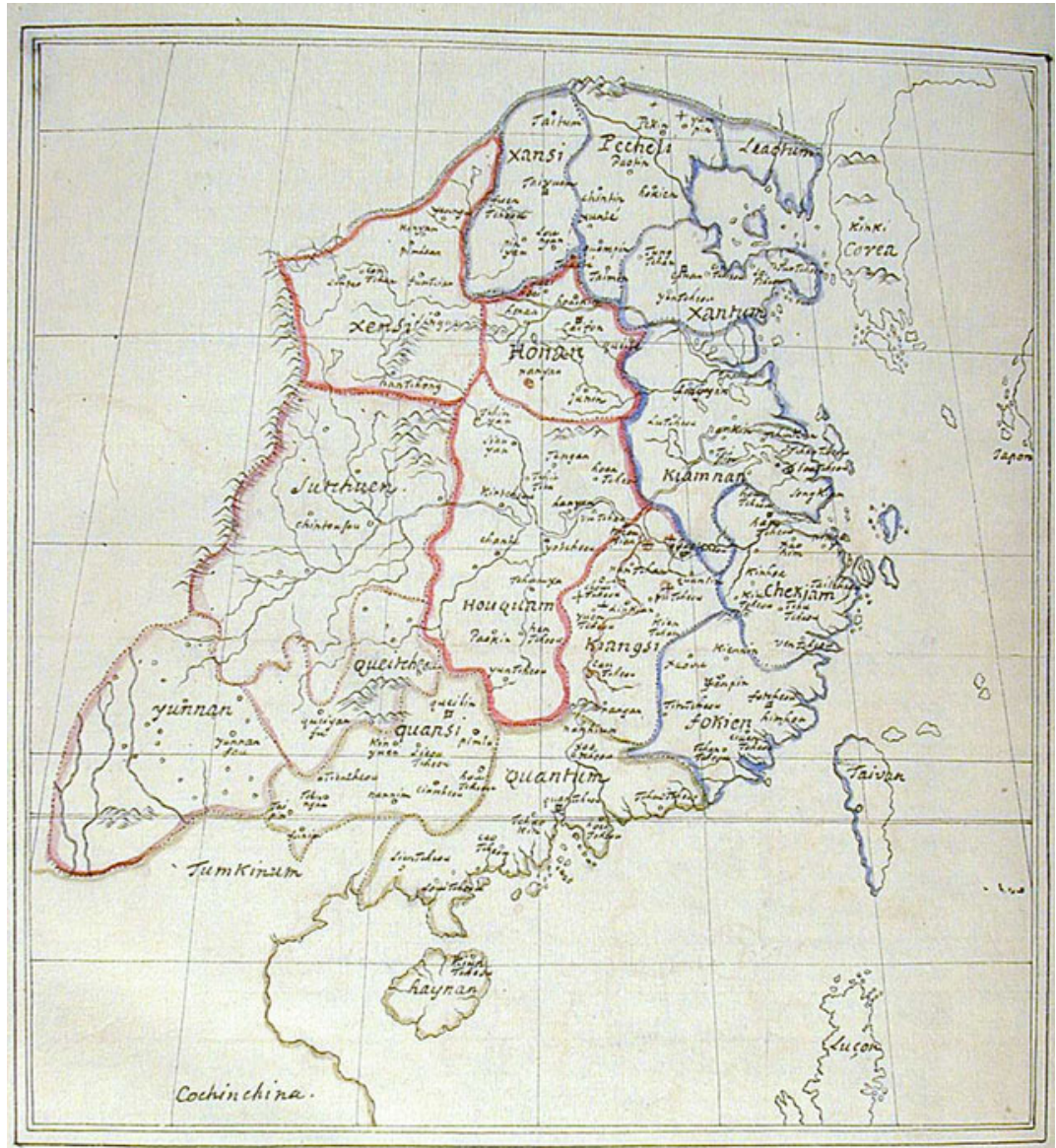

Map 4.1 Organization of Jesuit Missions in Ming China Source: AMRIM/ARSJ, Jap.Sin. 181, Epistola Sinarum, f. 001

world (Menegon 2009; Standaert 2001; Spence 1985). For instance, the surname of San Francisco Xavier was fám 方, the name of Father Matteo Ricci (1552-1610) (Meynard 2013) was Li Mádòu 利玛窧, and Father Michele Ruggieri (1543-1607) was known in China as Luó Mingjiān 罗 明坚. 
Thus, they were the first to romanize the Chinese language by creating the first Sino-Japanese-Latin dictionary (see Illustration 4.3). Some examples of this process of romanization from Chinese to Latin can be observed through words such as heaven "cieli," 天 tiān, and they wrote "thier," which means that they were adapting the dictionary more to the phonological features of the Mandarin dialect of the late Ming dynasty. The dictionary was not based on the northern Beijing dialect, being likely

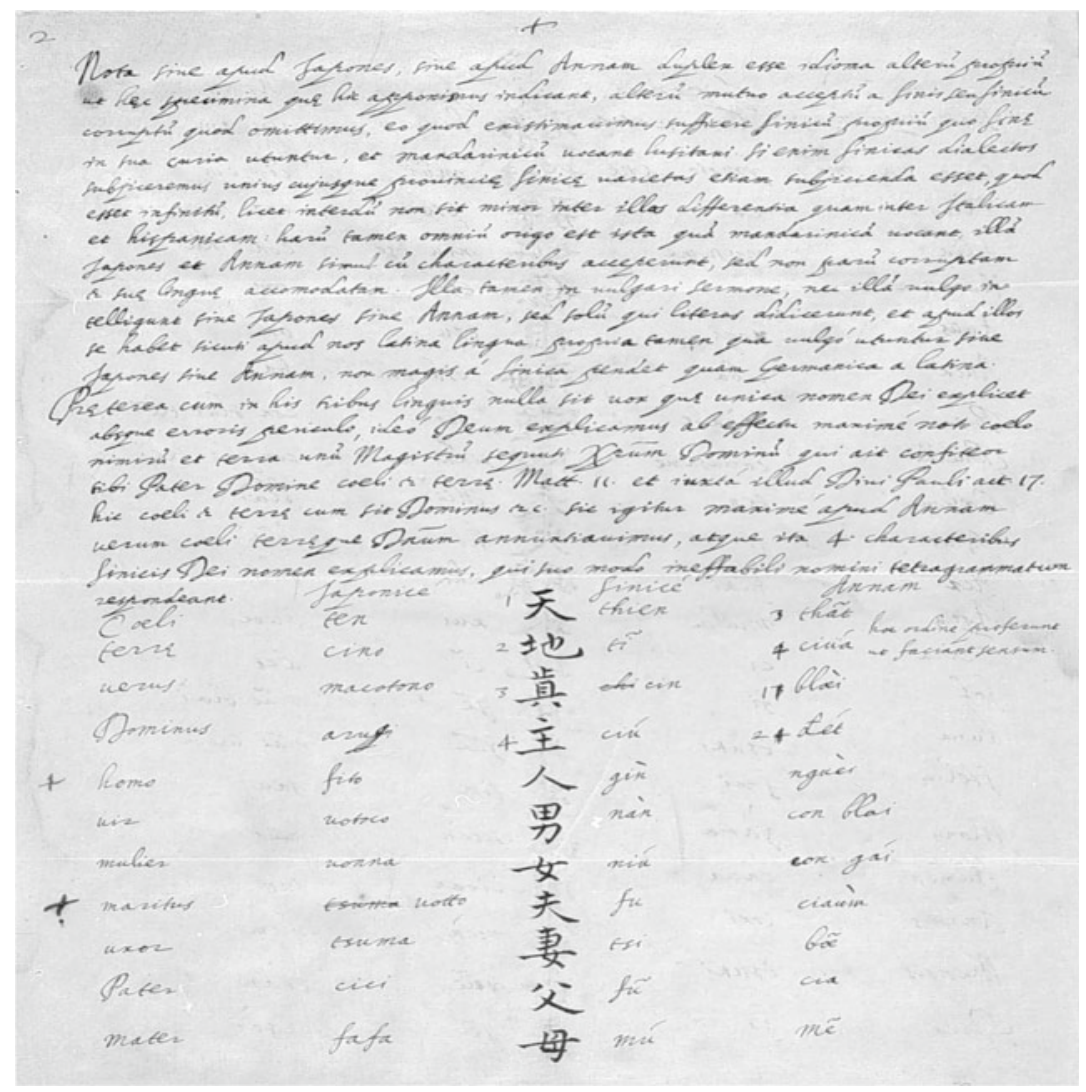

Illustration 4.3 Preparation of a Sino-Japanese-Latin dictionary by Ruggieri and Ricci, circa 1583-1588

Source: AMRIM /ARSJ, Jap. Sin. 187 
more based on the dialect of Nanking and its surroundings Ricci and Ruggieri also prepared a Sino-Portuguese dictionary between 1583 and 1588 (Witek 2001: 208-209).

\subsection{Sangleyes and European Networks in Macao and Manila: Decentralizing THE SPANish and QING Empires}

The process of evangelization carried out by the Augustinians alongside the Spanish monarchy's economic project in the Philippines were reminiscent of the strategies involved during the Spanish reconquest of the Moors; land occupation, repopulation, and establishment of institutions and integration of peoples of non-Catholic faith (Perez-Garcia 2020; Ruiz 2004; Herzog 2015). Similarly, as in the territories of Spanish America, the Crown established the encomienda system in the Philippines, endowing the extraction of rents, tributes, and lands to Spanish colonizers and religious orders such as the Dominicans and Augustinians.

The transfer of such benefits and tributes provided the Spanish elites and religious orders a stable source of revenue. However, as in the Americas, some difficulties were found in the repartimientos de indios or "the temporary distribution of Indians as a workforce for the colonizers" (Yun-Casalilla 2019: 57; Jauregui and Aguilar 2005; Parry 1990; Romano 2004), where in the case of Manila the Chinese sangleyes were the main workforce. This was an endogenous factor that contributed to the long-run stagnation of the Philippines' economy as it also had in the Americas (Elson 2013; Coatsworth 2008).

Spaniards often found resistance to their requests for labour and taxation among indigenous populations. Additionally, abuse within the encomiendas was common, as several episodes from July 1578 indicate, revealing the lack of control and poor administration by the Spanish elites and colonizers in Manila. There was the case of the factor [worker] of ships Andres de Mirandaola who quarrelled with Diego Lopez de Valdepeñas for the poor tax collection, accusing him of diverting the money for his own benefit. ${ }^{18}$ There were also some testimonies that the encomiendas of Guido de Lavezaris were misused causing great damage to

18 AGI, Filipinas, 29, n. 29. 
the Real Hacienda de Filipinas [Royal Treasury of the Philippines]. ${ }^{19}$ It was mentioned that rice from these encomiendas was given to the Indians of the villages of Bitis and Lubao, Chinese settlers and Philippine natives, instead of Spanish officials and soldiers, and that royal soldiers and officials had sacked much of the land. ${ }^{20}$

Before the arrival of Domingo de Salazar (first bishop of the Philippines) (Gutierrez 1976) and the Governor General Gonzalo de Ronquillo's establishment of the Manila Parian as a place of residence for Chinese merchants in 1581 (Cervera 2015; Ollé 2008; Pastells et al. 1925; Aduarte 1640; de la Costa 1950), the Augustinians were entrusted to settle the sangleyes and work with them in the village named Miton (which they renamed Santa Fe). They were in charge of the doctrine of Christianity to convert the sangleyes to the Catholic faith as well as employing them as the main human capital to economically develop the area. In a memorial the Augustinian friar Andres de Aguirre, padre provincial [provincial father], wrote that:

...to convert to the Chinese that comes to trade in Manila and they have settled down there, they have been moved to a nearby place to Manila named Miton as it is called in the language of the indios [Indians], and a Church has been erected by two friars, but the bishop has made the proper errands to take this village for its Church. He asks to protect this village to the Augustinian Order and monastery, and to rename the village as Santa $\mathrm{Fe}$, and its monastery San Felipe...21

Figures on the number of sangleyes settled in Manila are not very accurate. Diego Aduarte mentions that when the Dominicans arrived in Manila in 1587 the number of sangleyes settled in the Parian ranged from 8000 to 15,000 (Aduarte 1640: 171). From early on it is mentioned in Spanish documents that sangleyes were ruthless people and orientated in business and accumulating capital (mainly American silver). Local Spanish elites had serious problems communicating with them as their language was difficult to understand " no se les entiende bien...y al fin son indios... hasta que yo trate de averiguar con todos la verdad andaban dando voces cada

\footnotetext{
19 AGI, Filipinas, 29, n. 29.

20 AGI, Filipinas, 29, n. 29.

21 AGI, Filipinas, 79, n. 14.
} 
uno" [it is impossible to understand....after all they are Indians...until I found the truth with all of them they were yelling...]. ${ }^{22}$

The sangleyes stopped settling down in the village of Miton. The documents also show that the sangleyes participated in the slave trade as slave owners [núli fànzi 奴隶贩子] (de Sousa 2010), and that they used the "reos" [prisoners] as forced labour and engaged in business partnerships [commenda] with the captains of vessels. Spanish merchants who were bringing goods from the Americas and Spain, fostering price speculation, were also forcing the "alcaldes mayores" [mayors] and other Spanish officials in the Philippines to buy commodities at a low price. ${ }^{23}$

This practice continued from the sixteenth century to the eighteenth century, being a major problem for the Habsburgs and Bourbon monarchs of Spain, as the Pacific trade, mainly Manila-Macao-Canton trade node, was the main channel that was funnelling the Spanish silver to China and away from the royal treasury of the Spanish empire whose decline started in the late sixteenth century. Regulations, royal decrees, and even building a new social archetype, the sangleyes, in the Spanish Asian colonies did not prevent the loss of Spanish economic resources.

One strategy that aimed to regulate the Atlantic and Pacific commerce was the loss of the monopoly trade by the city of Seville to the port of Cadiz (del Valle Pavon 2011). Such practices were consolidated from times of the Iberian Union of Crowns (1580-1640) (Schaub 2001) under the Habsburgs to the eighteenth century with the arrival of the French Bourbon dynasty to the Spanish throne. Intellectual enlighteners and ministers hoped to regulate commerce in the Pacific (Bonialian 2012) with the establishment of the Real Compañia de Filipinas [Royal Company of Philippines] (Díaz-Trechuelo 1965) or the open-trade royal decree to open commerce in several Spanish ports in the second half of the eighteenth century.

Unregulated trade and smuggling activities were prompted by the constant drain of American silver into China, via Manila-Macao-Canton, from the sixteenth century onwards. Silver had become the standard payment for transactions and exchanges, as well as the main currency for the fiscal system, particularly since paper money [báo chāo 宝钞 ] had

22 AGI, Filipinas, 339, 1. 2, f. 55r-56r.

AGI, Filipinas, 79, n. 14.

23 AGI, Filipinas, 339, 1. 2, f. 55r-56r.

AGI, Filipinas, 79, n. 14. 
resulted in inflation and copper coin production had proved insufficient (Von Glahn 2019). Silver was introduced as the main standard after some monetary reforms were introduced by the Ming emperor Xuande in 1436 when he accepted the "Gold Floral Silver" [jin buza yin 金花银] (Huang 1974: 52; Von Glahn 1996; Twitchett and Grimm 1988). Later in the early sixteenth century the "Single Whip Reform" (Grass 2017: 7-31; Wan and Shu 2015) recognized that silver was officially and legally the main unit for transactions and tax collection. However, the Ming dynasty silver mines, located in Guizhou, Henan, Shanxi, Shandong, Zhejiang, Fujian, Sichuan, and Yunnan, as Ming shilì (Records of Ming Dynasty) reports, did not have enough production of silver. ${ }^{24}$ The government had only 100,000 silver tael income from domestic silver mines every year (Wan 2004).

These conditions paved the way for the constant influx of American silver into Ming and Qing China. The shortage in domestic silver production could hardly meet the increasing demand, so the Ming government was forced to open maritime trade. Overall, the thirst for silver as payment and the shortage in the supply of this precious metal stimulated a rise in price. Selling silver to the Chinese turned out to be a fat bargain. With the trade surplus advantage, gross inflow of foreign silver met the growing demand for silver money in the middle and late Ming dynasty. In addition, the growing demand in the Americas and Europe for Chinese goods such as silk, porcelain, and tea contributed to the vast amounts of American silver entering China (see Table 4.2).

The arrival of Portuguese and Spanish traders to Macao and Manila was the final factor in consolidating the flow of silver from the Americas to China. Wang Yuxun points out that 1586 was a turning point in this inflow. According to his findings, prior to 1586 about 300,000 pesos of American silver came into China every year (Wang 1998). After that the number rapidly increased which is correlated with the settlement of Spanish colonizers and the sangley community in Manila. From 1586 to 1590 approximately 2,500,000 pesos came into China. Until the end of sixteenth century the volume of American silver in China imported from Manila amounted to two or three million pesos. Liang Fangzhong's statistics shows that $6,800,000$ yuan of American silver entered China from

24 SJTUL, Ming shilu (Veritable Records of the Ming Dynasty), Taipei: Academia Sinica Institute of History and Philology, 1962. 
Table 4.2 The amount of silver from Spain-controlled Americas that entered the East via Europe, 1500-1800

\begin{tabular}{cccc}
\hline Year & $\begin{array}{c}\text { Production of silver in } \\
\text { Spain-controlled Americas }\end{array}$ & $\begin{array}{c}\text { The amount of silver } \\
\text { that entered Europe }\end{array}$ & $\begin{array}{c}\text { The amount of silver } \\
\text { transferred to the East }\end{array}$ \\
\hline 1550 & 3 & 3 & $2-3$ \\
1600 & $11-14$ & 10 & 4.4 \\
1650 & $10-13$ & $8-9$ & 6 \\
1700 & 12 & $10-12$ & 8.5 \\
1750 & $18-20$ & $18-25$ & 12.2 \\
1780 & 22 & $18-20$ & 14.7 \\
1800 & 30 & $23-35$ & 18 \\
\hline
\end{tabular}

Unit: Millions of yuan

Source: Attman (1986, p. 33)

1721 to 1740 and $105,000,000$ yuan from 1752 to 1800 (Liang 1953; Liang 1989).

Quan Hansheng (1966) surmised that from 1700 to 1830 five billion yuan [one silver yuan equals circa 0.72 tael] (Faure 2006, 2007: 58) of American silver arrived in China. He accepted the assumption that nearly two thirds (Attman 1986; Dermigny 1964; Chaunu 1962; Atwell 2005; Flynn and Giraldez 1996) of silver was transferred from the Americas to Manila and then finally transported by Chinese merchants (the sangleyes) to China via Macao, Canton, and Fujian as the main trade nodes. However, he corrected his figures in later works declaring that circa six and a half billion yuan were transferred to Macao-Canton through Manila (Quan 1969).

Almost half of the American silver was absorbed by Chinese markets in the late Ming dynasty, China being the largest silver consumer at that period (Quan 1972; Wan 2004). In this framework the sangleyes of Manila played a crucial role in the late sixteenth and early seventeenthcentury diversion of American silver and tax revenue from the Spanish royal treasury to local traders of south China, mainly those from Macao, Canton, and Fujian. As can be seen in Fig. 4.1 and Map 4.2, a high volume of tax revenue to the royal treasury in the Philippines came from the trade with south China, especially Canton, through the licences granted to the sangleyes.

The data provided in Fig. 4.1-although constrained to one yearillustrates the seasonality of south China's maritime trade due to weather 


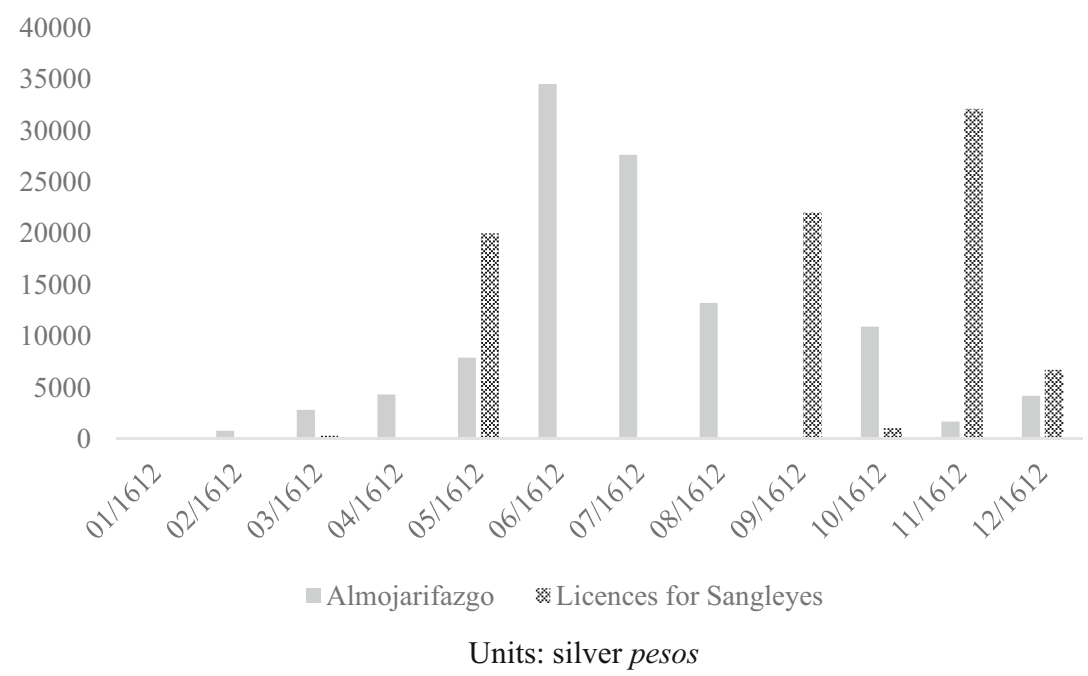

Fig. 4.1 Trade tax revenue of the Spanish royal treasury in the Philippines, 1612

Source: AGI, Contaduría, Cajas Reales de las Islas Filipinas, 1209, f. 640r.-670v

conditions, agriculture, sea-faring activities, and piracy (van Dyke 2017, 2011). The tax revenue accounts were arranged randomly according to such factors. Mark Elvin analysed the system according to the Chinese lunar calendar and defined it as "year-node divisions" related to the solar periods in which the Chinese lunar calendar is divided (Elvin 1973: 350). The licences granted to the sangleyes, who on many occasions were linked to smuggling and unofficial trade, accounted for a higher value than the almojarifazgo revenue in the autumn of 1612 (see Fig. 4.1 and Map 4.2).

Granting a higher number of licences to sangleyes was a way the Spanish authorities devised to somehow control and regulate trade between the colonies (the Philippines) and south China. This was a daunting and unrealistic task, as trade along the coasts of Canton and Macao and the routes connecting to Manila were rife with piracy and smuggling (Antony 2010). In practice the regulation of commerce was in the hands of the local authorities and elites of the Philippines, which acted through non-official channels and coalitions with smugglers along the Manila-Macao-Canton main trade artery connecting south China with American and European territories. 


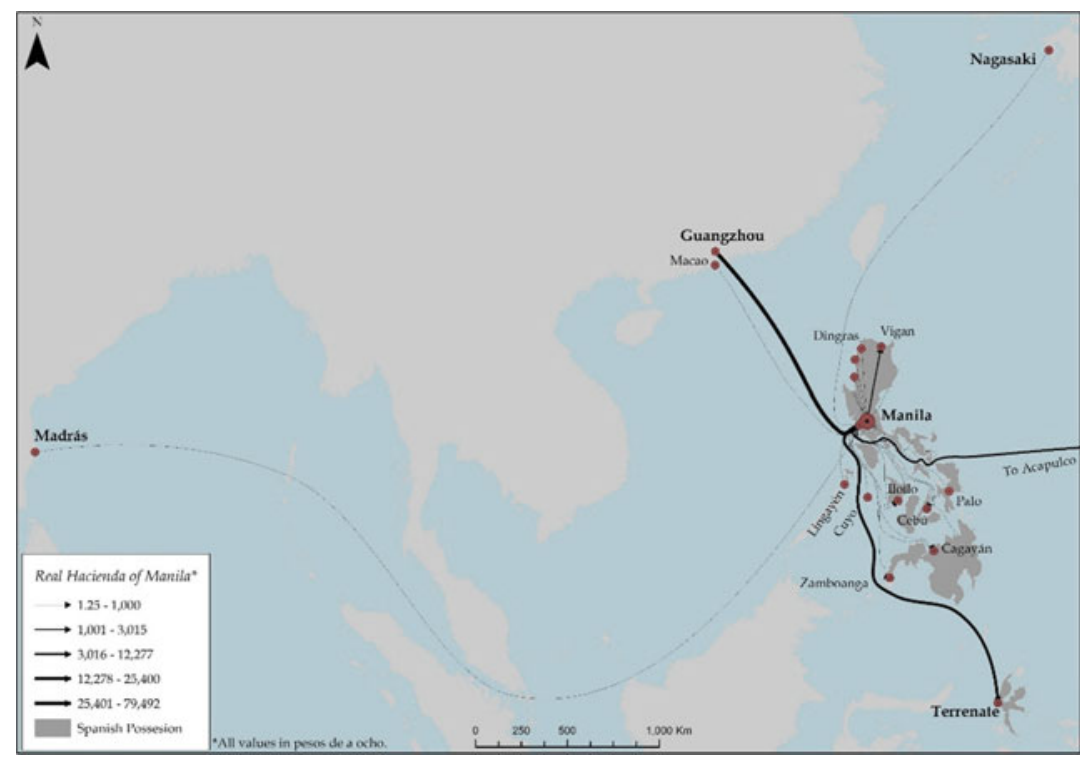

Map 4.2 Trade tax revenue of the Spanish royal treasury in the Philippines, 1612

Source: Author's own elaboration, through GECEM Project Database and Software QGIS v3.12 Base map from Natural Earth raster through data of AGI, Contaduría, Cajas Reales de las Islas Filipinas, 1209, f. 640r.-670v

This trade system that began in the sixteenth century was consolidated over the seventeenth and eighteenth centuries through trade networks and business partnerships between European, American, and Chinese merchants connecting big, medium, and small companies that shared information and capital. The main mercantile system for such exchanges was through letters of credit and contracts for American silver and goods (i.e. silk, tea, or porcelain from China, and European red wines and liquors, as major evidence I have found) enabling a third partner through the so-called commenda contract (Pryor 1977) in which small companies or societies were engaged with a non-official business system to ship goods and carry on transactions.

The sangleyes were the main agents and mediators in such exchanges since Manila was the nexus for the flow of American silver and exchange of Western and Chinese goods through the trade networks that connected 
agents from several origins (East Asia, southeast Asia, the Americas, Europe) (Schurz 1939; Shiu and Keller 2007; Suarez 2018). A brokerage system was consolidated through global trade networks that were formed in local spaces connecting Europe and the Americas with the port cities of Macao, Canton, Xiamen (Amoy), Ningbo, and Shanghai ( $\mathrm{Ng} \mathrm{1983).}$ The commenda, defined as a commercial form of cooperation, integrated several agents and transactors, pooled capital, shared risks, and investments (Reinert and Fredona 2017), as well as profits among the participant agents. Originating in medieval Europe, the commenda (van Doosselaere 2009; Greif 2006; Trivellato 2009; Mauro 1990) was found in Ming and, mainly Qing China, where overseas trade connecting the Pacific regions (Manila, Macao, Canton, and also Nagasaki) via Manila galleons had a high risk (among major risks were piracy, shipwrecks, wars, price speculation in south China markets, or the sudden disappearance of one of the partners or contractors). And there were other problems with this mercantile system in terms of trust and loyalty regarding the business partners as the letters they exchanged show:

...I received a letter that from Mr. Obry and which contains a bond and a certification that you gave to Mr. Bene which was given the Sangley of some goods of mine sold on credit. I was astonished as when I sent you a letter to the city of Mansiloc you replied me that the Sangley said that there were not any goods or money for me, and now I see that you have given a certification of my own goods. If I didn't see it and I wouldn't have seen it with your own signature herein, I wouldn't believe it! But I am in the obligation to believe it or explode in fury; I am grateful for the favors you have made me, and I can only say that you must remember that the mountains are not found but men do...25

This letter was written by the governor of the Philippines, don Simon de Anda y Salazar in 1762 complaining to his partners don Juan Solano and don Jorge de Sanclemente who lived in Masinloc (a province of Zambales in the Philippines) about the payment of a silk cargo bought in Macao and Canton. The sangley merchant entrusted to carry on this business through

25 The original letter was written in Spanish. Herein I present the English translation for a better understanding of the reader. Arquivo Historico de Macau (thereafter AHM), Catalogue of the Swedish East India Company (hereafter CSEIC) /Nordiska Museet (hereafter NM) /The Godegard Archive (hereafter GA), Series: F17, vol. 1A, vol. ID: 17:1A and vol. 1 B, vol. ID: F17:1B, Grill Letters, ref. T1_00729. 
credit had delayed delivery on the goods (Chinese silks from Nanjing and Suzhou) to be resold in Marseille. Such delay was infuriating the governor of the Philippines.

Solano and Sanclemente took 500 silver pesos from the company, led by John Abraham Grill and don Simon de Anda, and the governor gave 91.5 pesos to the sangley to buy the silk manufactures in Canton and ship them to Manila to the governor who would resend them to Marseille through his subsidiary companies. ${ }^{26}$ Painted silk cloaks with gold and silver embroidery with a value of 336 silver pesos, silk skirts with a value of 61 silver pesos, plus a commission of $2.5 \%$ (12.4 silver pesos) out of 500 silver pesos was the total amount of goods and silver. This is an outstanding example of the commenda form as the main business instrument undertaken by trade networks connecting China with European markets. It is also very important to mention the British blockage of the Philippines in this period that caused serious damage to the above-mentioned transactions which elevated the business risks.

The Brunet family, Nicolas de Sollicoffre (French citizen and Swedish consul in Marseille), the Roux family, and the Grill family stand out as relevant agents who created a dense trade network connecting big trade houses with subsidiary companies and individuals that had business in Stockholm (Müller 2004), Amsterdam, London, Cartagena, Cadiz, Seville, Veracruz, Lima, Acapulco, Manila, Macao, and Canton. ${ }^{27}$ Financers from Marseille and Montpellier integrated local markets in western Mediterranean Europe, the Americas, and south China (Hamashita 2015) creating a non-official mercantile system that bypassed the control of both Qing and Spanish empires.

The sangleyes from Manila and the Hong merchants of Canton were the main business agents and partners that perpetuated this brokerage system in the eighteenth century which might be defined as an "AsianMediterranean brokerage system" (Perez-Garcia 2013; Gipouloux 2011). Through loans of credit and high interest rates these brokers developed

${ }^{26}$ AHM, CSEIC Series: F17, vol. 1A, vol. ID: 17:1A and vol. 1 B, vol. ID: F17:1B, Grill Letters, ref. T1_00730.

27 AHM, Documentary CSEIC /NM /G, Series: F17, vol. 1A, vol. ID: 17:1A and vol. 1 B, vol. ID: F17:1B, Grill Letters, ref. T1_00734.

Archivo Municipal de Cartagena (hereafter AMC), Actas Capitulares (hereafter AcCap), 20-12-1712.

AMC, AcCap 30-12-1712. 
profitable transactions by buying Chinese silk at low prices and selling it to European traders, and selling European wines and liquors at high prices in Canton markets.

The high risk behind this trade system can be observed through the debts and risks that traders settled in Macao incurred during the eighteenth and nineteenth centuries. In many cases the loans of silver reached an interest rate of 35\% or even more ( $\mathrm{Ng} \mathrm{1983;} \mathrm{Von} \mathrm{Glahn} \mathrm{1996).} \mathrm{The}$ Santa Casa de Misericordia de Macao [Holy House of Mercy of Macao] (Díaz de Seabra 2011; de Sousa 2019) acted as the main institution that channelized the finances and investments of the above-mentioned overseas trade covering risks. Portuguese traders (Souza 1986) issued letters of credit and loans to finance such overseas ventures. It was a very risky system, but very profitable. However, due to the main features involved in this trade such as an unregulated market, piracy, and instability caused by the British occupation of the Philippines, among the more relevant conditions, the Holy House of Mercy of Macao was in debt in the last quarter of the eighteenth century and early nineteenth century (see Fig. 4.2).

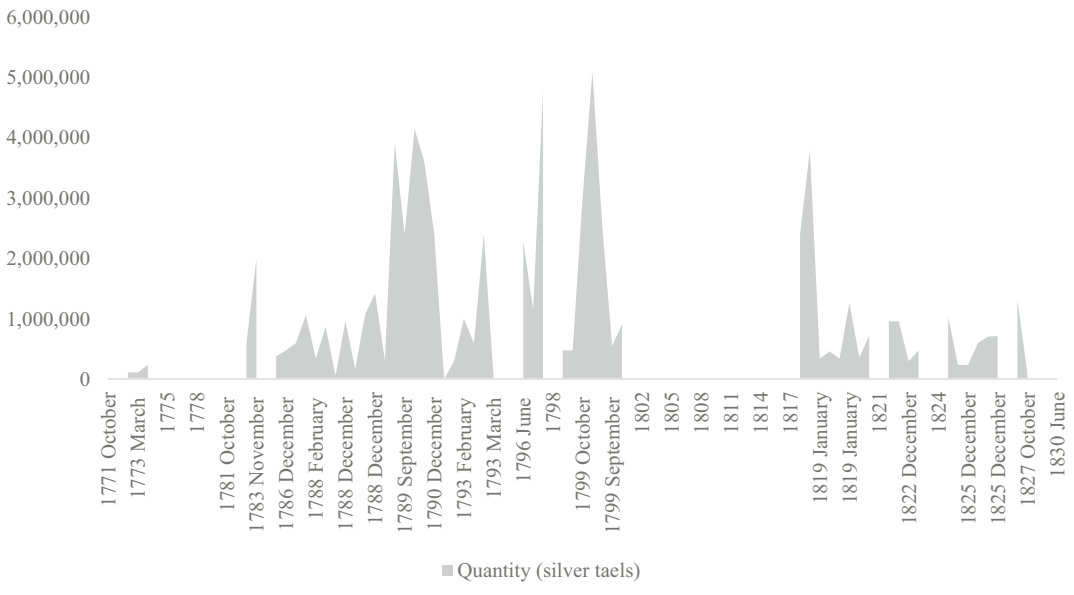

Fig. 4.2 Debts of the Holy House of Mercy of Macao, 1771-1830

Source: Arquivo Historico de Santa Casa de Misericordia de Macao (hereafter $\mathrm{AH} / \mathrm{SCM}$ ) /40 — 'Livro da Conta Corrente dos Mutuários: Dívidas à Santa Casa da Misericórdia (1771/10/30 a 1804/10/22)', f. 6v.-10. Díaz de Seabra [2011] 


\subsection{Integrating South Europe and South China Markets: The Case of Macao and Marseille}

As an interdisciplinary field global studies has gained a lot of terrain during the last decade, especially with the focus on the processes of socio-cultural transfers that fostered the consumption and circulation of exotic commodities such as tea, porcelain, or ornate clothing in Europe from Asian territories, especially China and India. But what can we say about socio-cultural transfers in southern European and southern Chinese markets through new comparative case studies? Certainly, there was a progressive consolidated market for Western goods in southern Chinese provinces such as Guangzhou and Fujian, with Macao as the main entrepôt (Flores 2000), because as discussed previously American silver was introduced into Chinese markets in the early sixteenth century. This prompted a rising consumption of Western and American goods in Ming and Qing China. European colonies in Asia were the main trade nodes and arteries that fuelled exchanges of Chinese and Western commodities.

Portuguese families, as the first Europeans who arrived in Macao in the sixteenth century (Subrahmanyam 1993), created solid trade networks by being the main mediators and agents of the Jesuit (Menegon et al. 2018) and Sephardim (de Sousa 2010) groups who also interacted with the Armenian community of East Asia (Teles and Cunha 2008; Aghassian and Kévonian 1999; Curtin 1984; Disney 1989). Such groups were settled in Macao and stimulated the consumption of Western commodities as well as the acquisition of new lifestyles by spreading new cultural habits and trade exchanges. The trade routes of the Manila galleons connected with main port cities of Macao, Guangzhou, Xiamen (Amoy), Ningbo, and Shanghai (Li 2010), but also with Taiwan, Korea, Japan, and the Southeast Asia region (see Map 4.3). Through such maritime trade networks in the South China Sea, goods such as tobacco, European red wines, and liquors (Perez-Garcia 2019), and American crops (Ho 1979; PerezGarcia 2018) (i.e. potato, sweet potato, chili, corn, among others) were introduced into southern Chinese provinces through the partnership and alliances between European and Chinese trade networks.

With the potential emulation of new socio-cultural standards through consumption of overseas goods, the inherent transcultural diversity of the network might be correlated with upper stages of economic growth as factors that could transform a traditional society to an open one. Marseille 


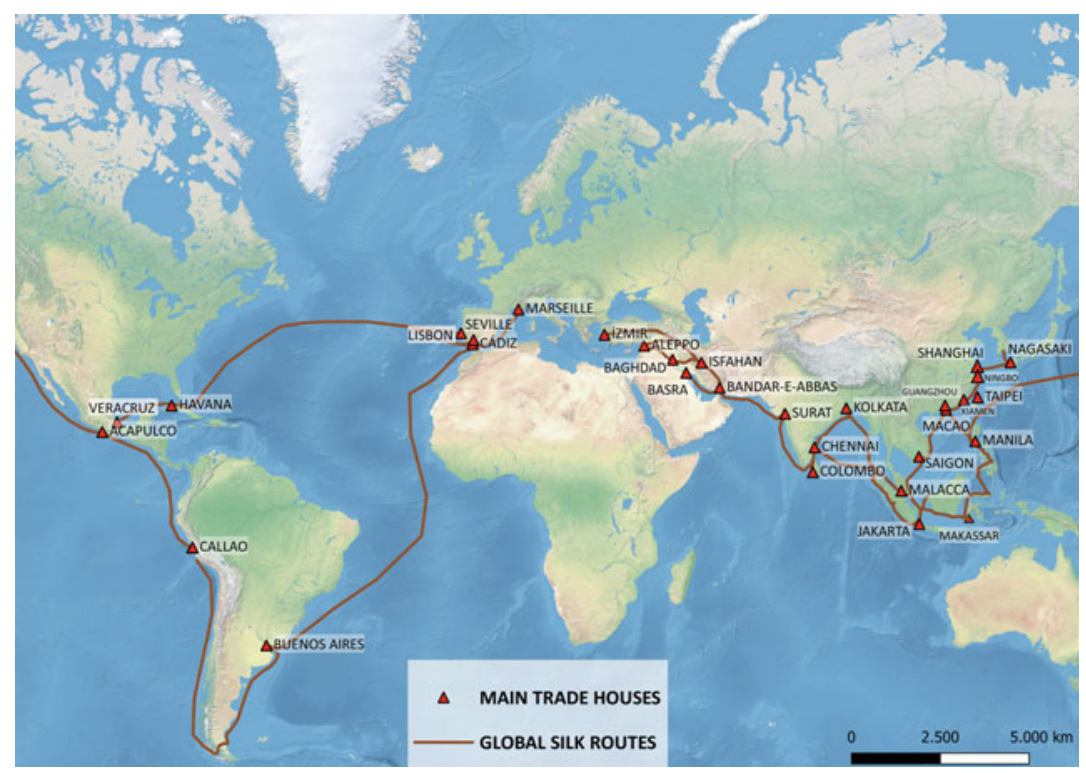

Map 4.3 Market integration between Asia, Europe, and the Americas through global silk routes, seventeenth to eighteenth century

Source: Author's own elaboration through GECEM Project Database and Software QGIS v3.12 Base map from Natural Earth raster through data of AGI, Contaduría [1289], Sobre las embarcaciones entradas en Filipinas, 1646-1758; Archive de la Chambre de Commerce de Marseille (hereafter ACCM); AHM, CSEIC, Grill Letters

and Macao, located in far off regions, are the paradigmatic examples of the progressive integration of long-distance markets and the potential transformation of open societies through global trade, circulation of overseas goods, American silver inflows, and development of modern financial systems to secure economic transactions.

Merchant networks that settled their companies in the port cities of Macao and Marseille exerted an essential role in the distribution and consumption of overseas goods. Thus my analysis of these trade networks focuses on merchant groups: their transnationality, the performance of the network at both local and macro scales (Trivellato 2009; Green 2013), as well as its socio-economic mutation in the places where these 
communities settled down according to factors such as trust, shared information, and partnership, all key factors to understanding the complexity of Sino-European commerce.

The most influential social actors of the Sino-European trade were the Portuguese who operated in the South China Sea with Macao as the main centre of business and economic exchange. Under the national flag of Portugal a diverse transnational group, mainly Jesuits and Sephardim (Trivellato 2003; Molho and Curto 2003), managed the network. Likewise, in western Mediterranean Europe, in Marseille, the main social groups that stimulated international commerce during the early modern period were the Armenians of New Julfa (Raveaux 2012; Aslanian 2011; Baladouni and Makepeace 1998) (see Fig. 4.3). However, with their expulsion from Marseille in the late seventeenth century they shifted their trade routes towards the Indian and Pacific Ocean through the interaction with the Compagnie française des Indes orientales and the East India Company (Carrière 1973).

Olivier Raveaux has made an accurate analysis of these Armenians who introduced goods from Asian markets, especially from distribution centres in Persia (Raveaux 2012: 86), where Chinese silks, semi-elaborated and

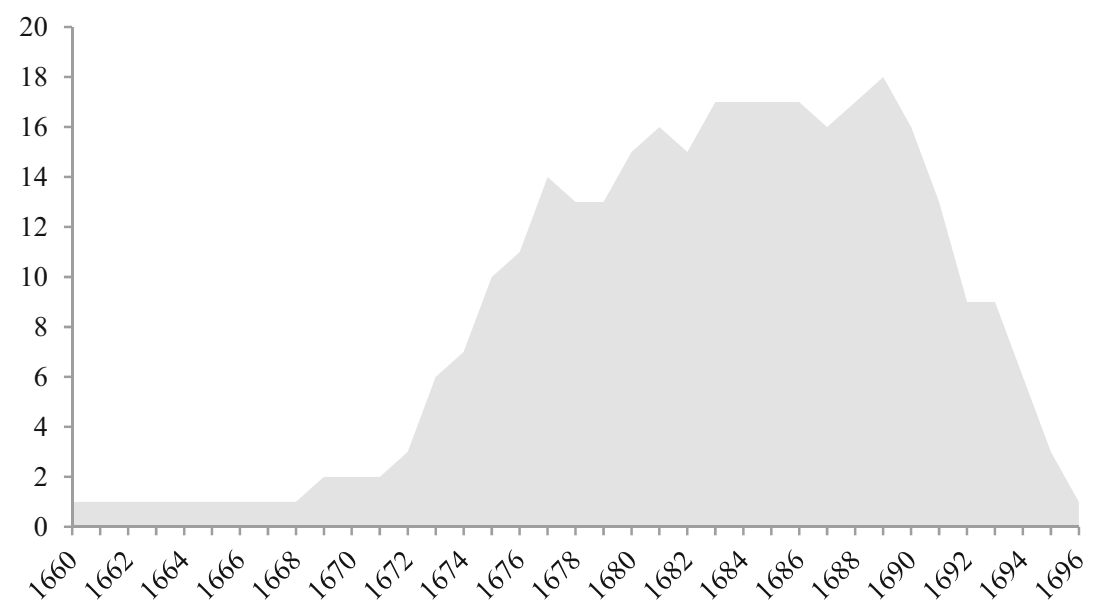

Fig. 4.3 Presence of Armenians in Marseille, 1660-1696

Source: Archives Departamentales des Bouches-du-Rhône (ADBDR). In Raveaux [2012: 85, 101] 
ready-made goods arrived from Chinese markets through the old Silk Road. These Armenian traders were known as Choffelins (Raveaux 2012: 89) since their origin was from New Julfa (Ispahan, capital of the Persia Safavid in the seventeenth century) and they were defined as itinerant merchants practising the commenda in the same way that the sangleyes and European (Spanish and Portuguese) traders in Manila, Macao, and Canton did, as discussed earlier. They specialized in the silk trade from Asia and the Levant which shows that they were key players in the redistribution and export of silks from China and Middle East Asian regions, as the mediators and main agents for this market between eastern and western regions (Aghassian and Kévonian 1999).

Analysing these inter-group relations offers a precise understanding of the internal organization of trading diasporas and merchant coalitions. The main goal of such interconnected groups was the self-interest of individual actions that can be observed in the micro and macro forms of the network itself. Through the spatiality and agency marked by the global commerce, these merchants integrated east Asian and Western markets. Thus, the geographical and spatial variables were relevant factors to observing the mobility of these groups and how Western and Eastern markets were integrated.

The Mediterranean market in the eighteenth century with Marseille as main entrepôt was connected to the Atlantic and the Pacific via the route Manila-Acapulco and Veracruz linking with Lisbon, Cadiz-Seville, Marseille, and northern markets such as Amsterdam and Stockholm (see Maps 4.3 and 4.4). Beyond the realm of the official route of the Spanish empire, Manila-Acapulco, unofficial trade and contraband operated in South American markets through the nodes Lima-Callao-Buenos Aires (Ibarra 2017; Suarez 2018; Bonialian 2012).

Marseille and Mediterranean localities were also integrated into Far Eastern markets through Indian and intra-Asian trade routes (Gipouloux 2011; Carriére 1973; Raveaux 2012; Aghassian and Kévonian 1999), with Armenian, Sephardi traders, Portuguese, and Mediterranean coalitions of merchants (i.e. French, Italian, Maltese, and Spanish, see Fig. 4.5), as well as northern European groups settled in Marseille and Cadiz such as the Grill family, all composing a transnational network that operated in a polycentric, highly decentralized market connecting Europe, Asia, and the Americas (see Maps 4.3 and 4.4). Such networks and economic agents stimulated Eurasian commerce such as the Swedish Grill company that established business in Macao and Canton in the eighteenth century (see Fig. 4.4) (Perez-Garcia 2019). 

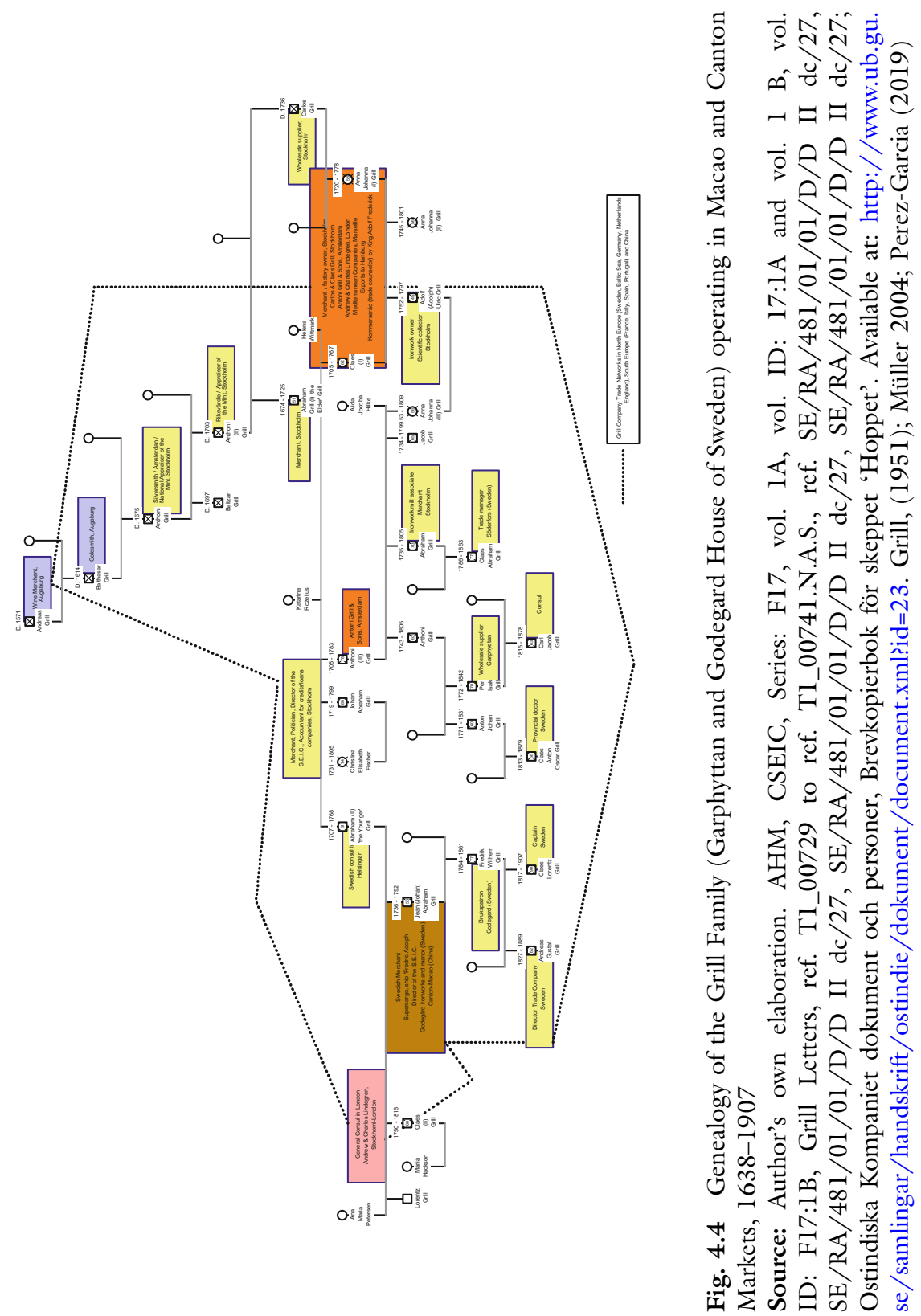
Itinerant merchants such as the Armenians of New Julfa, the sangleyes of Manila, European trade companies settled in Macao, the Chinese Hong merchants of Canton, and subsidiary companies and partners in American markets (Ibarra 2019; Bonialian 2012; Martinez-Shaw 2007; Malamoud 1986) were collectively connected with western Mediterranean traders and were the key agents bypassing official institutions. This transnational community integrated Eurasian trade arteries by land and sea connecting the Indian Ocean and the Mediterranean Sea through the routes of the Red Sea and the intra-Asian routes, the so-called silk routes via Aleppo and New Julfa (see Map 4.4) (Baladouni and Makepeae 1998; Aslanian 2011).

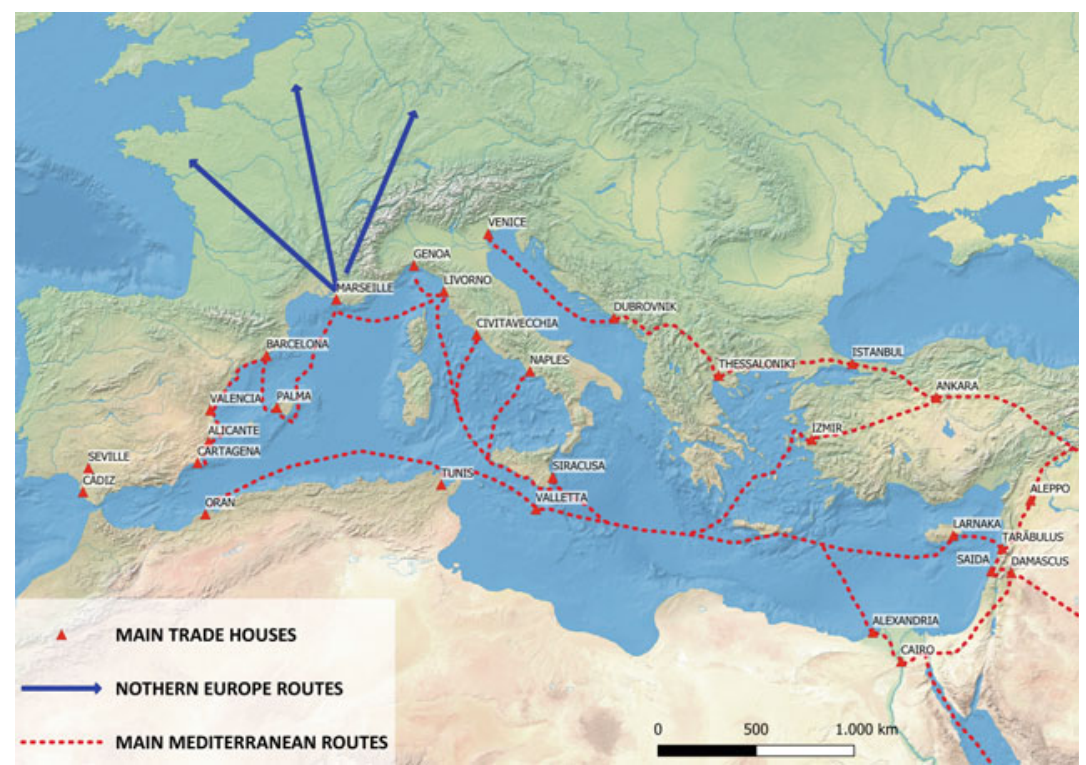

Map 4.4 Roux company trade houses in Mediterranean silk routes connecting Marseille with the Near East, eighteenth century

Source: Author's own elaboration through GECEM Project Database and Software QGIS v3.12 Base map from Natural Earth raster through data of ACCM 
This polycentric market developed a bilateral cooperation between European companies and those that operated in East Asia, more specifically in Macao, as the main linchpin that connected Qing China with Western powers. A good example of this can be found in the coalition between the Armenian and French traders, who jointly operated in Marseille and Macao, as well as in Manila with the sangleyes and Spanish local elites. The effect of this decentralized and unregulated trade system boosted the accumulation of capital (American silver) by Western and Eastern traders.

The consolidation of these commercial networks stimulated in Europe, and more precisely in western Mediterranean regions, the consumption of Asian goods such as tea, porcelain, furniture, clothing, and textiles made of Asian cottons and silk. The paradigmatic example is the circulation of Chinese silks (semi-elaborated and manufactured) in western Mediterranean markets. These goods were introduced during the eighteenth century (Perez-Garcia 2013; Carrière 1973) in Marseille and from there re-exported to other Mediterranean ports such as Barcelona, Valencia, Alicante, Cartagena, Cadiz, and Seville.

The main agents for the redistribution of Asian (Chinese) silks in the western Mediterranean were transnational trade groups and subsidiary companies such as Estoup, Cayron, Martin, Bouyon, Vidal, Cailus, Dachiary, Aubour, Davide, Funes, Peretti, Pericano, Peseto, Pesano, Sizilia, Socori, Sese, or Ycar (see Fig. 4.5). These small groups were dependent on the big trade houses led by the Roux or Grill family both established in Marseille. These groups created a "Mediterranean emporium" in localities of Genoa, Civitavecchia, La Valeta, Bearn, Oloron, Auvergne, Lyon, Marseille, and Cartagena, as the most relevant places that have been found in the historical sources (see Map 4.4). These trade networks consolidated connections with local and foreign elites of western Mediterranean, American, and East Asian areas (Perez-Garcia 2011; Bartolomei 2007; Buti 2005).

During the early modern period, wholesalers, small retailers, peddlers, and family groups, who mainly operated in the Mediterranean and the South China Sea such as Macao, Canton, Fujian, Manila, or Taiwan, established strategies based on marriage alliances with the aim of perpetuating and boosting business activities that provided high benefits (see Figs. 4.6, 4.7). Within this empirical evidence the nature and origin of relevant social actors and family groups that benefited from East Asian trade has been identified. 


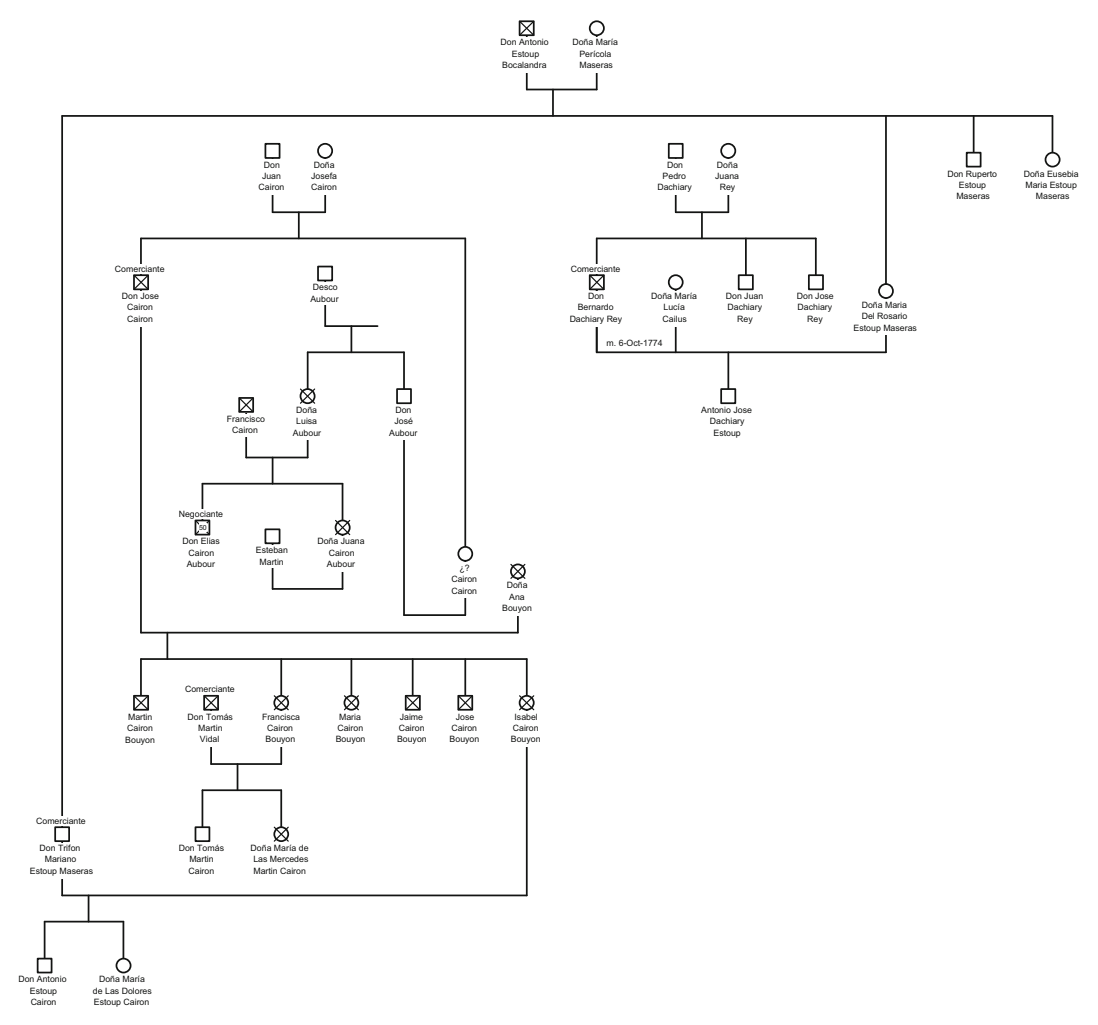

Fig. 4.5 French-Italian-Maltese trade coalitions: Genealogy of the StoupCayron family, seventeenth to eighteenth century

Source: Author's own elaboration. Protocols of the Archivo Histórico Provincial de Murcia, Spain [hereafter AHPM]

There are several examples of merchants who ran businesses in Macao (Boxer 1959; Boyajian 2008) during the seventeenth century (de Sousa 2019; Souza 1986; Bonialian 2012), such as the companies of Francisco Xavier Doutel and Luis Sanchez de Casares, who traded zinc, porcelain, sugar, or copper. They engaged in marriage strategies with conational groups and local communities creating a transnational network between Portuguese and Dutch families with local groups of Taiwanese (Borao 2002, 2010) (see Fig. 4.7). This trade system and socio-economic 


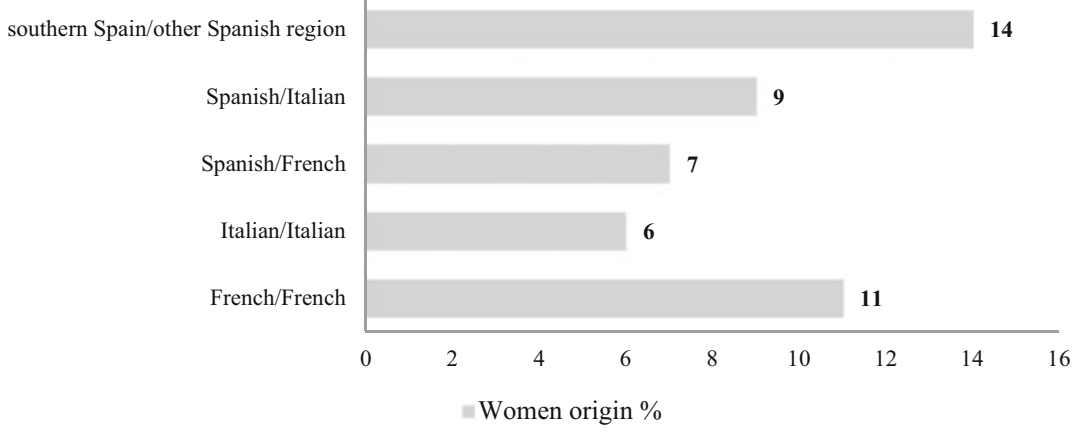

Fig. 4.6 Co-national and transnational marriages among Mediterranean merchants in Southeastern Spain (1730-1808)

Source: Author's own elaboration. AHPM

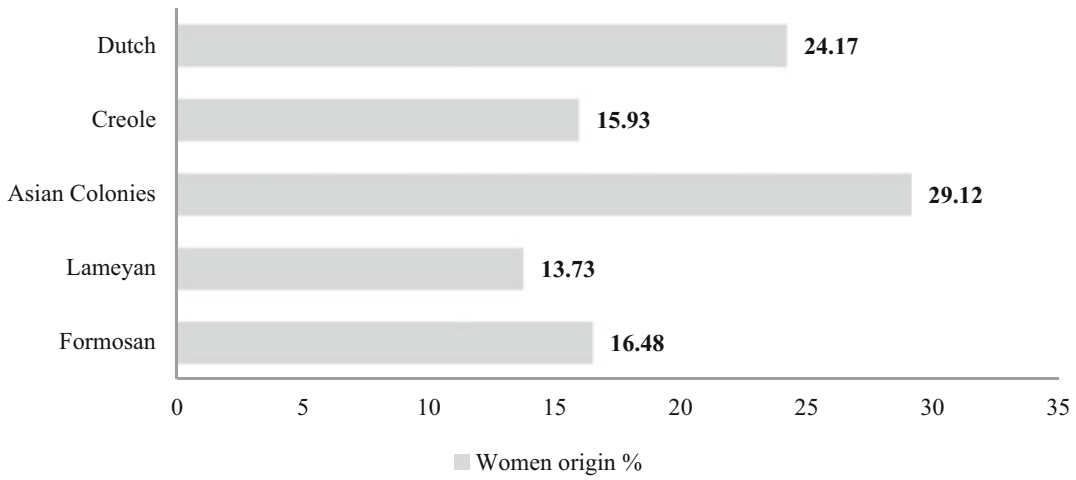

Fig. 4.7 Transnational marriages in Taiwan, seventeenth century Source: Author's own elaboration. Borao [2002]; Heyns and Cheng [2005]

alliances started in the sixteenth century, continued in the seventeenth century, and was consolidated during the eighteenth century.

The growing transactions in Macao and Canton through dense trade networks and partnerships by European and Chinese traders led to the Qing government to implement changes within the then-current trade policies. With the lifting of the official ban on overseas trade in 1684, Qing officials established a series of customs posts and Beijing created positions of custom superintendents such as the Hìbì户部, popularly 
known as "hoppos" (Van Dyke 2011: 7-9), in the provinces of Guangdong, Fujian, Zhejiang, and Jiangsu. This stimulated Chinese commerce with foreigners, with Canton, Macao, Taiwan, and Manila as the main trade zone in which the Sino-European, and more precisely Spanish and Portuguese, business activities operated (Boxer 1958; Yuste Lopez 2007). However, there were very strong tariff restrictions attached to this trade with China. The imposition of taxes such as the almojarifazgo [royal tariffs levied in the ports of the Spanish empire ${ }^{28}$ were in most cases disregarded by merchants, mainly the sangleyes of Manila (Chaunu 1960; Schurz 1939) who carried on Chinese good exchanges with European traders by not declaring such goods at port customs and fostering contraband in the south China trade routes. Figures of the total volume of trade, data of shipping and arrivals, and the almojarifazgo levied in the Philippines can be found at the Archivo General de Indias, which gives us an overview of the official measures undertaken by the Spanish monarchy to clamp down on tax evasion and contraband.

In October 1714 royal officials in the Philippines reported to the Spanish king Philip V that the price of a licence granted to the sangleyes to allow them to trade in the Philippines had increased to 1 silver peso and 2 tomines. ${ }^{29}$ Furthermore, an additional $2 \%$ was added to the existing $6 \%$ that was in previous years charged for the derechos reales de almojarifazgo [royal rights for the almojarifazgo] collection for the ship cargoes that come to the Philippine islands. This tariff, to be charged from the month of January to December, was applied from 1714 onwards. In 1718 the number of licences rose and revenue stood at 2800 silver pesos; in 1719 revenue was 1606 silver pesos. ${ }^{30}$

The changes in the almojarifazgo levied by Spanish royal officials in the Philippines changed from $5 \%$ to $8 \%$, and in other years almost reached $10 \%$, which helps explain the sharp fluctuations in the tax collection of

\footnotetext{
28 The term almojarifazgo comes from the Muslim word al-musrif meaning supervisor in charge of collecting custom fees at the gates of cities and Muslim ports. The official in charge of levying this tax, the almojarife, was one of the most important positions of the Castilian Real Hacienda [Royal Treasury] until the fifteenth century as this official managed the local treasure for the Spanish monarch in every new conquest land (Gonzalez de Arce 2007: 13). This of course applied for the Spanish American colonies and the Philippines.

29 Fraction of $1 / 8$ of silver peso.

30 AGI, Contaduría, 1289, Caja de Filipinas, 1646-1758.
} 


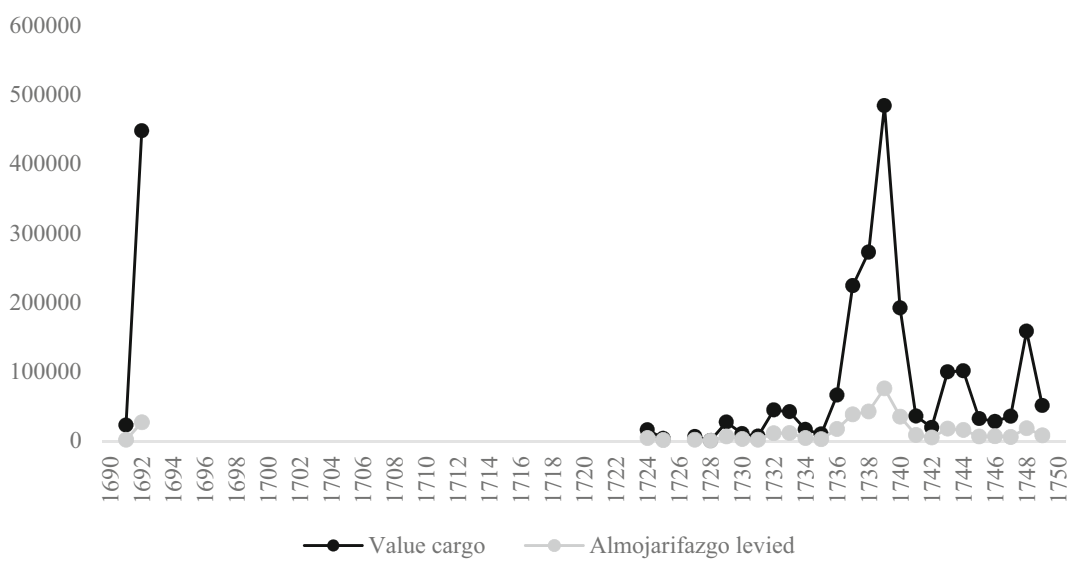

Fig. 4.8 Almojarifazgo levied in Manila of ships arrived from China, 16901750

Source: Author's own elaboration. AGI, Contaduría,1289, Sobre las embarcaciones entradas en Filipinas, 1646-1758

the almojarifazgo mainly in the years from 1738 to 1740 and from 1743 to 1745 (see Fig. 4.8). The sample of sources arranged at the Archivo General de Indias (Spain) of the ships arriving from Chinese ports to Manila for the period from 1690 to 1750 is 577 ships $^{31}$ in which the total value of the cargo and almojarifazgo collected is registered.

For these periods the frequency of ships arriving from China to Manila (see the data of Fig. 4.8), mainly from the ports of Amoy (Xiamen), Canton, and Macao, were higher than in the rest of the years as this period is prior to the establishment of the Canton system [y $\bar{k} k o ̛ u$ tôngshāng 一口 通商] by the Qianlong emperor setting Canton as the only port to trade with Western powers. In addition, the formation of the Cohong by the Yongzheng emperor fostered the trade monopoly with Manila by the elite and merchant groups of Canton, Macao, and also from Fujian province who were mainly engaged in smuggling activities.

Another important factor to consider is that the evaluation of goods shipped was normally less than the real value of the cargo as officials disregarded it due to technical inefficiency or corruption practices between

31 AGI, Contaduría, 1289, Sobre las embarcaciones entradas en Filipinas, 1646-1758. 
the captain and officials. In addition, Manila was not the place where the sales were made, so the value of the real transaction is not estimated. The value in many cases was arbitrarily calculated by royal officials. This was a common practice in the Spanish-controlled colonies (Moutoukias 1988; Walker 1979; Lamikiz 2011). As Katherine Bjork (1998) documented in her work for the case of Acapulco and Veracruz that despite officials' ad valorem rates imposed over the cargo for the application of almojarifazo, $5 \%$ and $8 \%$ as for the case of Manila presented herein (see Fig. 4.8), or in other cases $10 \%$ as in Veracruz (TePask and Klein 1986), duties were charged arbitrarily and did not follow a standard manner and constant rate, contrary to William L. Schurz's thesis (1939), which only occurred in the markets of Mexico City or Madrid.

The frequency of ships arriving in Manila from Macao and the almojarifazgo levied from 1735 to 1745 (see Fig. 4.8) was affected by the strong dependence of Macao on foreign trade. This provoked cyclical economic crisis in Macao whenever there was a loss of ships and vessels due to shipwrecks and piracy and this happened in the above-mentioned period (1735-1745). The economic and political hegemony of the Netherlands and Great Britain which was rising in the East Asian region provoked Joao $\mathrm{V}$, the King of Portugal, to issue a decree in 1746 prohibiting foreigners from settling down and trading in Macao (Boyajian 2008; de Sousa 2019; Souza 1986). However, the Portuguese monarch made an exception for vessels coming from Manila as they could freely trade being subject to pay less tributes, only 1.5\%, whereas Portuguese and other inhabitants of Macao were subject to pay 2\% (Bruxo et al. 2017; Carneiro de Sousa 2014; Carneiro de Sousa 2010; Caldeira 2007).

When analysing dramatic variations of the almojarifazgo in Fig. 4.8 for the periods from 1690 to 1692,1738 to 1740 , and from 1743 to 1745, some other factors should also be considered: (1) The lump sum for the payment of almojarifazgo of a period of years was imposed in a one-year payment. (2) The political context of Qing China for the time periods mentioned included three different emperors, the so-called "High Qing” period [shèng qing 盛清] (Kangxi, Yongzheng, and Qianlong). Kangxi (1661-1722) established some reforms such as setting maritime customs duties which brought about some wealth but the last years of his reign saw increased corruption and expenditure on military campaigns which negated any gains (Rowe 2009). Yongzheng (1722-1735) introduced some reforms (Porter 2016; Rowe 2009; Elliott 2001) to eradicate corruption such as the creation of the Grand Council (Bartlett 1991), 
and the grouping of Chinese merchant houses in Canton into one single institution, the Cohong [gōng háng 公行] (Po 2018; Rawski 1998; Van Dyke 2011) in 1725 to control trade. The Cohong preceded the main reform on trade introduced by Qianlong (1733-1796) who established Canton as the only port in China allowed to trade with foreign powers, the so-called Canton system [yīkǒu tōngshāng 一口通商] (Van Dyke 2005; Gao and Feng 2003). (3) The European (Spanish) political context which included the War of the Spanish Succession (1701-1714) (Kamen 2001) which ended with the arrival of the French Bourbon dynasty to the Spanish throne. And the War of Jenkins' Ear or guerra del asiento (17391748) in Spain between Britain and Spain for the control of the asiento [licence granted by the Spanish crown by which merchants obtained the monopoly on a trade route or good] as the British wanted to gain access to Spanish markets (Martinez-Shaw and Mola 2013; MartinezShaw 1982). Later in 1756 the British blockaded Manila and thereafter they occupied the Philippine islands between 1762 and 1764 (Danley and Speelman 2012; Borschberg 2004; Fish 2003).

Behind the rivalry between the Spanish and British empires to be the economic and politic hegemonic power overseas, there was a complex system structure (Gibbons 2001) in which the different players, Spain, England, and also France and the local elites of the Philippines, selforganized their decisions according to the international relations scenario and rationality for decision making on trade and social networks. Whereas Spain and England were engaged in maritime disputes to control trade, French trading houses and small companies seized an opportunity in this conflict to engage in alliances with Manila elites and Macao and Canton traders and brokers (mainly the Manila sangleyes). This prompted a progressive creation of spatial and unofficial networks that were interfering in Spanish trade zones and in the East Asian region dismissing the economic and political power of Spain.

Illustrative examples are the trade networks established by the French Roux company and the Swedish Grill House with Manila, Macao, and Canton elites and traders through a dense network of small companies and intermediaries composed of the Brunet, Sollicoffre, Simon de Anda y Salazar (governor of the Philippines), Bene, Obry, Cayron, Dumond, Sanclemente, Poankeequa [Pan Zhencheng 潘振承 president of the Cohong in Canton], among the more relevant socio-economic actors (Perez-Garcia 2019; Van Dyke 2017: 6). 
This set of factors made commerce in the South China Sea between Manila and Chinese ports very fluctuant, and according to official sources (see Fig. 4.8) very difficult to estimate, as officials (like their Chinese counterparts in Macao and Canton) did not perform their duties due to the rampant corruption, contraband, and bribes they received (Barrett 1990). Contraband of silver shipments, mainly silk exports from China to the Americas and Europe, via Manila and Indian Ocean routes, was very profitable due to the increasing demand for Chinese silks in Western markets.

The formation and consolidation of the above-mentioned alliances are testified in a series of letters, the so-called Grill letters, in which the Cohong Poankeequa [Pankequa], Johan Abraham Grill, the captain and governor of the Philippines, Gregorio Chang (sangley in Manila), and the French merchant Dumond were dealing with cargoes of silk. ${ }^{32}$ Different typologies of silks to be introduced via the Americas (Acapulco-Veracruz) to Mediterranean markets with Marseille as main entrepôt of redistribution to other European territories were checked by Pankequa and Grill sending samples of silks to show the quality: “...about the qualities of these cargoes and other goods that were introduced in Manila by the Indian [Chinese sangleyes] were sent to the Philippines to Acapulco and Europe."33 The high volumes and circulation of American silver pesos to buy these silks and clothing (see Fig. 4.9) were emphasized in these letters and transactions.

Silks from Lanquin [Nanquin] were those that were exported in highest volumes from China to western Mediterranean cities such as Marseille and Seville. The city of Nanquin is Nanjing, from Jiangsu province, whose name was the same as Nanjing county in Fujian because the governor of Jiangsu had there a residence as described by Matteo Ricci's diaries and the Flemish Jesuit Nicolas Trigault. Father Trigault edited and updated Ricci's diaries and accounts of the Jesuit China mission, and in his work De Christiana expeditione apd Sinas Suscepta ab Societate Jesu translated from Italian to Latin and thereafter in Spanish gave an accurate reference about Nanjing:

32 AHM, CSEIC Series: F17, vol. 1A, vol. ID: 17:1A and vol. 1 B, vol. ID: F17:1B, Grill Letters, ref. T1_00732.

33 AHM, CSEIC Series: F17, vol. 1A, vol. ID: 17:1A and vol. 1 B, vol. ID: F17:1B, Grill Letters, ref. T1_00732. 


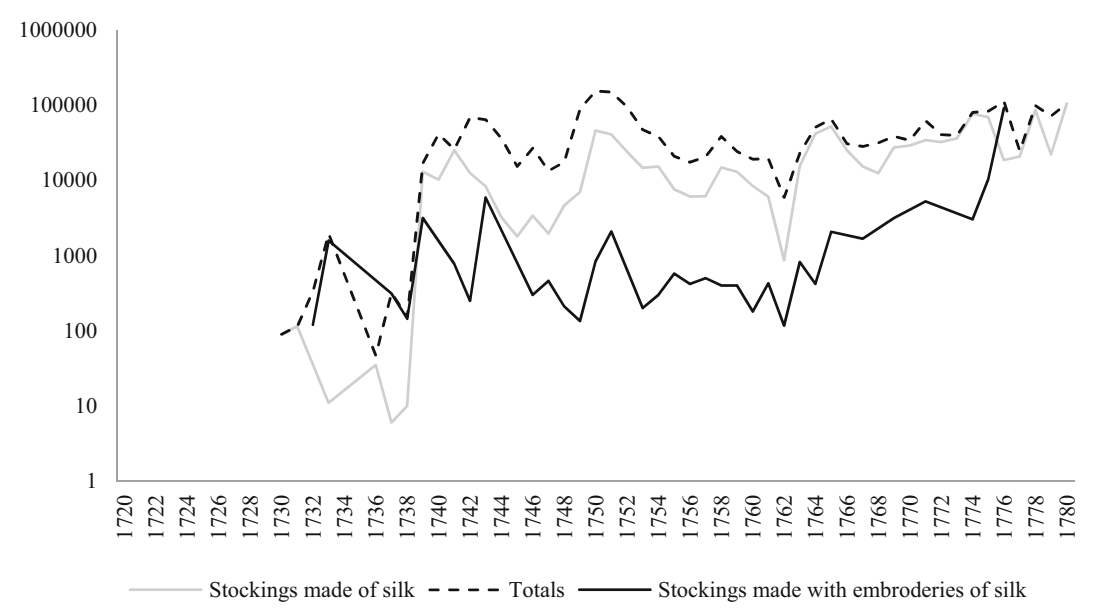

Fig. 4.9 Re-exportation of stockings made of silk from Marseille to Spanish Mediterranean ports, 1720-1780

Source: ACCM, Statistique. Serie I

"This metropolis is named Nanquin, however the Portuguese who heard about this city by which the inhabitants of the city of the province of Fuquien [Fujian] called it Lanquin; because in their language the letter $\mathrm{N}$ is changed as L. By the name of other city by which is called in this region [Fujian] with the name of Nanjing [of Jiangsu province], because the governor of this city has a residence there..."34

Thus, the import-export market prompted changes in patterns of consumption in western Mediterranean Europe and south China, via the ports of Marseille and Macao, connecting inner China through Macao and Canton, and Marseille with Spanish Mediterranean markets of Barcelona, Valencia, Alicante, Cartagena, Cadiz, and Seville. The entry of these Chinese silks and manufactures (see Fig. 4.9) were introducing new fashions, tastes, and lifestyles creating a new middle class. Merchants can be defined, therefore, as "vicarious consumers" (Perez-Garcia 2013, 2019) who stimulated changes in consumer behaviour. The illustrative

34 TBCL, Rare Book Collection, Trigault, N., De Christiana expeditione apd Sinas Suscepta ab Societate Jesu, Lugduni: Horatij Cardon, 1616, chapter X, p. 143. 
example of the parishes of the city of Seville for the first half of the eighteenth century (see Map 4.5) shows the rising level of consumption of Chinese silks and clothing in middle-class households such as merchants and artisans, as well as the local nobility.

These changes in patterns of consumption and the rising demand for Chinese goods (silk in the case presented in this chapter) was prompted through the polycentric markets and trade networks operating in the Pacific where smuggling activities and unofficial trade during the seventeenth and eighteenth centuries became the main channel of diffusion into European markets. The intrusion of French trading houses in the Manila, Macao, and Canton markets, mainly dominated by the Spanish and Portuguese crowns, provoked a dislocation of the structure of the networks and strategies according to the new political context of the

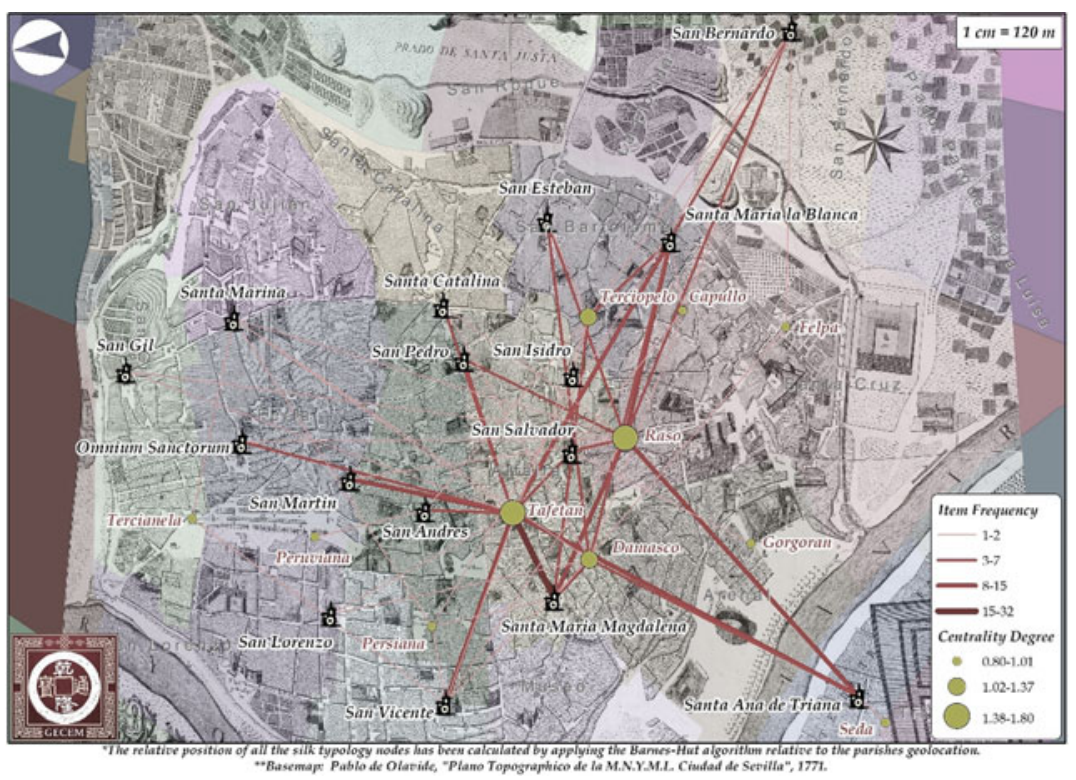

Map 4.5 Typologies of Chinese silks and consumer's networks in the parishes of Seville, 1727-1750

Source: Author's own elaboration through GECEM Project Database and Software QGIS v3.12 Base map from Natural Earth raster through data of protocols and probate-inventories of the Archivo Provincial de Sevilla (hereafter AHPS) 
eighteenth century. The smuggling culture behind the commerce of the South China Sea, with Macao as the main strategic port of such transactions, contrasted with trade activities of western Mediterranean markets, mainly Marseille, in which commerce was more regulated. Trade exchanges in the South China Sea were defined by contraband or informal commerce (Shimada 2006). For this reason, the state capacity of the Spanish monarchy was too weak to organize trade in the Philippines and control the traffic and cargoes of the Manila galleons (Cheong 1997; Stein and Stein 2000).

This level of contraband, and the inefficiency of institutions and officials to regulate trade and organize the economy of the Spanish colonies in the Pacific, was endemic within the Spanish monarchy ever since the early arrival of Dominican and Augustinian friars and Spanish elites to the Philippines. Trade relations with China were never well regulated. For instance, Pedro de Vargas in 1655 travelled to Northern Vietnam, Tunquin [Tonkin], to buy goods to be resold in Manila without paying taxes. ${ }^{35}$ His licence to trade in the kingdom of Tonkin was suspended by Juan de Bolivar y Cruz, fiscal [prosecutor for the government] of the Real Audiencia de Manila [Royal Audience of Manila]. A letter was sent to the Spanish king pleading for the official cancellation of de Vargas' licence. The report made by the fiscal also mentioned that several champanes [ships] had sailed to the kingdoms of Conchinchina, Siam, Camboya, and Macao to also buy silks without declaring the royal taxes in silver and gold.

Such suspension was due to the contradictions declared in the Audience by Pedro de Vargas to trade in Tonkin with his champan because it raised suspicions of potential contraband and illegal activities. ${ }^{36}$ This demonstrated that both Spanish and Chinese merchants hardly paid royal taxes [the almojarifazgo]. Therefore, ships that arrived in the Philippines from Xiamen [Amoy], Canton, Macao, Gulf of Tonkin, and Manila were inefficiently supervised by overseers or accountants.

The socio-cultural transfers related to the assimilation of new cultural forms and daily habits, through the consumption of Chinese goods (silks) for example, consequently brought changes in fashions and habits. By analysing the role and function of merchants and their networks in Europe

35 AGI, Filipinas, 22, r. 7, n. 24, Manila, 19-07-1655.

36 AGI, Filipinas, 22, r. 7, n. 24, Manila, 19-07-1655. 
and East Asia, it is possible to shed light on changes in patterns of consumption and, therefore, the formation of long-distance business partnerships. Marseille and Macao can be defined as central transnational regions, where overseas goods circulated beyond the official realm of the Spanish and Qing empires.

These two port cities are the key territories in order to see how European cultural transfers took place in south China through Macao and how Chinese goods penetrated into Europe through Marseille as the main Mediterranean entrepôt of the eighteenth century. Both places connected the West and the East and were the main trade nodes that integrated south China and Mediterranean markets through the mediation of transnational agents (i.e. merchants, missionaries, travellers, diplomats).

Open Access This chapter is licensed under the terms of the Creative Commons Attribution 4.0 International License (http://creativecommons.org/licenses/ by $/ 4.0 /)$, which permits use, sharing, adaptation, distribution and reproduction in any medium or format, as long as you give appropriate credit to the original author(s) and the source, provide a link to the Creative Commons license and indicate if changes were made.

The images or other third party material in this chapter are included in the chapter's Creative Commons license, unless indicated otherwise in a credit line to the material. If material is not included in the chapter's Creative Commons license and your intended use is not permitted by statutory regulation or exceeds the permitted use, you will need to obtain permission directly from the copyright holder.

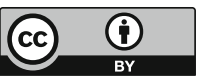

